\title{
SGD
} Sosyal Güvenlik Dergisi
Journal of Social Security

P-ISSN: 2146-4839

E-ISSN: 2148-483X

\section{Bireysel Emeklilik Sistemine Analitik Bakış: Yoğunlaşma ve Yapısal Kırılma Analizi}

\section{Analytical View of the Individual Pension System: Concentration and Structural Break Analysis}

\author{
Sümeyra KARA
}

Türkiye Bilimsel ve Teknolojik Araştırma Kurumu

\section{Harun Türker KARA}

T.C. Sağlık Bakanlığı

Aralık 2020, Cilt 10, Say1 2, Sayfa 333-352

December 2020, Volume 10, Issue 2, Page

333-352

P-ISSN: $2146-4839$

E-ISSN: 2148-483X

$2020-2$

e-posta:sgd@sgk.gov.tr

Yazılar yayınlanmak üzere kabul edildiği takdirde, SGD elektronik ortamda tam metin olarak yayımlamak da dahil olmak üzere, tüm yayın haklarına sahip olacaktır. Yayınlanan yazılardaki görüşlerin sorumluluğu yazarlarına aittir. Yazı ve tablolardan kaynak gösterilerek alıntı yapılabilir.

If the manuscripts are accepted to be published, the SGD has the possession of right of publicationand the copyright of the manuscripts, included publishing the whole text in the digital area. Articles published in the journal represent solely the views of the authors.

Some parts of the articles and the tables can be citeded by showing the source. 


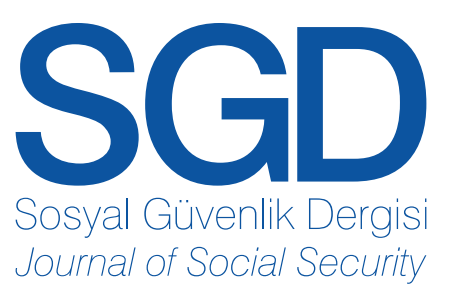

Cilt: 10 - Say1: 2 - Y11: 2020

Volume: 10 - Issue: 2 - Year: 2020

P-ISSN: 2146-4839

E-ISSN: 2148-483X

Sahibi / Owner of the Journal

Sosyal Güvenlik Kurumu Adına / On behalf of the Social Security Institution

İsmail YILMAZ

(Kurum Başkanı / President of the Institution)

Sorumlu Yazı İşleri Müdürü / Responsible Publication Manager

Uğur KORKMAZ

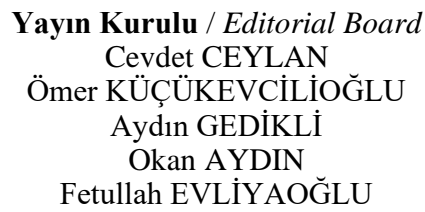

Editörler / Editors

Doç. Dr. Erdem CAM

Selda DEMİR

Redaksiyon / Redaction

Nihan ERTÜRK

Yayın Türü: Uluslararası Süreli Yayın / Type of Publication: International Periodical

Yayın Aralığı: 6 aylık / Frequency of Publication: Twice a Year

Dili: Türkçe ve İngilizce / Language: Turkish and English

Basım Tarihi / Press Date: 20.12.2020

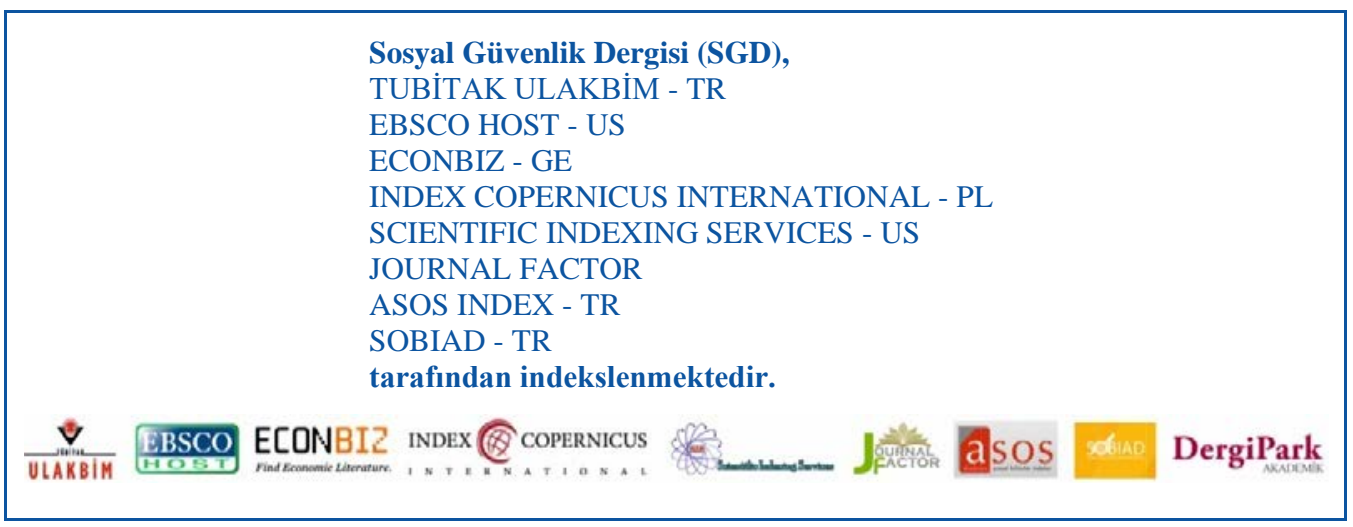

CTüm hakları saklıdır. Sosyal Güvenlik Dergisi’nde yer alan bilimsel çalışmaların bir kısmı ya da tamamı telif hakları saklı kalmak üzere eğitim, araştırma ve bilimsel amaçlarla çoğaltılabilir. Dergide yayımlanan makalelerdeki fikir ve görüşler Sosyal Güvenlik Kurumunun kurumsal görüşünü yansıtmaz, tüm görüşler yazarlarına aittir.

Tasarım / Design: PERSPEKTİF Matbaacılık Tasarım Tic.Ltd.Şti. (0 312) 3842055 - Ankara

Basım Yeri / Printed in: PERSPEKTİF Matbaacılık Tasarım Tic.Ltd.Şti. (0 312) 3842055 - Ankara

İletişim Bilgileri / Contact Information

Sosyal Güvenlik Kurumu Başkanlığı

Ziyabey Caddesi No: 6 Balgat / Ankara / TÜRKIYE

Tel / Phone: +90 3122078891 - 2078770 - Faks / Fax: +90 3122077819

Erişim/Webpage: http://www.sgk.gov.tr/wps/portal/sgk/sgd/tr - e-posta / e-mail: sgd@sgk.gov.tr 
Professor Yener ALTUNBAȘ

Bangor University - UK

Professor Paul Leonard GALLINA

Bishop’s University - CA

Professor Jacqueline S.ISMAEL

University of Calgary - CA
Professor Özay MEHMET

University of Carleton - CA

Professor Allan MOSCOVITCH

University of Carleton - CA

Professor Mark THOMPSON

University of British Columbia - CA
Asst. Prof. Sara HSU

State University of New York- USA

Asst. Prof. C. Rada Von ARNIM

University of Utah - USA

\section{ULUSAL DANIŞMA KURULU / NATIONAL ADVISORY BOARD}

Prof. Dr. Ahmet Cevat ACAR

İstanbul Üniversitesi

İşletme Fakültesi

Prof. Dr. İsmail AĞIRBAŞ

Ankara Üniversitesi

Sağlık Bilimleri Fakültesi

Prof. Dr. Levent AKIN

Ankara Üniversitesi

Hukuk Fakültesi

Prof. Dr. Yusuf ALPER

Bursa Uludağ Üniversitesi

İktisadi ve İdari Bilimler Fakültesi

Prof. Dr. Faruk ANDAÇ

Cağ Üniversitesi

Hukuk Fakültesi

Prof. Dr. Kadir ARICI

Ankara Hacı Bayram Veli Üniversitesi

Hukuk Fakültesi

Prof. Dr. Onur Ender ASLAN

Ankara Sosyal Bilimler Üniversitesi

Siyasal Bilgiler Fakültesi

Prof. Dr. Zakir AVŞAR

Ankara Hacı Bayram Veli Üniversitesi

İletișim Fakültesi

Prof. Dr. Ufuk AYDIN

İstanbul Aydın Üniversitesi

Hukuk Fakültesi

Prof. Dr. Abdurrahman AYHAN

Kıbris İlim Üniversitesi

Hukuk Fakültesi

Prof. Dr. Serpil AYTAÇ

Bursa Uludağ Üniversitesi

İktisadi ve İdari Bilimler Fakültesi

Prof. Dr. Mehmet BARCA

Ankara Sosyal Bilimler Üniversitesi

Siyasal Bilgiler Fakültesi

Prof. Dr. Süleyman BAŞTERZI

Ankara Üniversitesi

Hukuk Fakültesi

Prof. Dr. Nursen CANIKLİOĞLU

Marmara Üniversitesi

Hukuk Fakültesi

Prof. Dr. Fevzi DEMIR

Yaşar Üniversitesi

Hukuk Fakültesi
Prof. Dr. A. Murat DEMIRCİOĞLU

Yıldız Teknik Üniversitesi

Emekli Öğretim Üyesi

Prof. Dr. Ömer EKMEKÇI

İstanbul Üniversitesi

Hukuk Fakültesi

Prof. Dr. E. Murat ENGIN

Galatasaray Üniversitesi

Hukuk Fakültesi

Prof. Dr. Hediye ERGİN

Marmara Üniversitesi

İktisat Fakültesi

Prof. Dr. Şükran ERTÜRK

Dokuz Eylül Üniversitesi

Hukuk Fakültesi

Prof. Dr. Afsun Ezel ESATOĞLU

Ankara Üniversitesi

Sağlık Bilimleri Fakültesi

Prof. Dr. Ali GÜZEL

Kadir Has Üniversitesi

Hukuk Fakültesi

Prof. Dr. Alpay HEKIMLER

Tekirdağ Namık Kemal Üniversitesi

İktisadi ve İdari Bilimler Fakültesi

Prof. Dr. Oğuz KARADENIZ

Pamukkale Üniversitesi

İktisadi ve İdari Bilimler Fakültesi

Prof. Dr. Aşkın KESER

Bursa Uludağ Üniversitesi

İktisadi ve İdari Bilimler Fakültesi

Prof. Dr. Cem KILIC

TOBB Ekonomi ve Teknoloji Üniversitesi

İktisadi ve İdari Bilimler Fakültesi

Prof. Dr. Ali Riza OKUR

İstanbul Sabahattin Zaim Üniversitesi

Hukuk Fakültesi

Prof. Dr. Serdar SAYAN

TOBB Ekonomi ve Teknoloji Üniversitesi

İktisadi ve İdari Bilimler Fakültesi

Prof. Dr. Ali Nazım SÖZER

Yaşar Üniversitesi

Hukuk Fakültesi

Prof. Dr. Sarper SÜZEK

Atılım Üniversitesi

Hukuk Fakültesi
Prof. Dr. Müjdat SAKAR

Marmara Üniversitesi

İktisat Fakültesi

Prof. Dr. Savas TASKENT

İstanbul Teknik Üniversitesi

İşletme Fakültesi

Prof. Dr. Ferda YERDELEN TATOĞLU

İstanbul Üniversitesi

İktisat Fakültesi

Prof. Dr. Sabri TEKİR

İzmir Demokrasi Üniversitesi

İktisadi ve İdari Bilimler Fakültesi

Prof. Dr. Mehmet TOP

Hacettepe Üniversitesi

İktisadi ve İdari Bilimler Fakültesi

Prof. Dr. Türker TOPALHAN

Ankara Hacı Bayram Veli Üniversitesi

İktisadi ve İdari Bilimler Fakültesi

Prof. Dr. Aziz Can TUNCAY

Bahçeşehir Üniversitesi

Hukuk Fakültesi

Prof. Dr. M. Fatih USAN

Ankara Yıldırım Beyazıt Üniversitesi

Hukuk Fakültesi

Prof. Dr. Gülbiye YENIMAHALLELI

Ankara Üniversitesi

Sağlık Bilimleri Fakültesi

Doç. Dr. Gaye BAYCIK

Ankara Üniversitesi

Hukuk Fakültesi

Doc. Dr. Emel İSLAMOĞLU

Sakarya Üniversitesi

Siyasal Bilgiler Fakültesi

Doç. Dr. Saim OCAK

Marmara Üniversitesi

Hukuk Fakültesi

Doç. Dr. Ercüment ÖZKARACA

Marmara Üniversitesi

Hukuk Fakültesi

Doç. Dr. Sinem YILDIRIMALP

Sakarya Üniversitesi

Siyasal Bilgiler Fakültesi 
Prof. Dr. Levent AKIN

Ankara Üniversitesi

Hukuk Fakültesi

Prof. Dr. Yusuf ALPER

Bursa Uludağ Üniversitesi

İktisadi ve İdari Bilimler Fakültesi

Prof. Dr. Murat ATAN

Ankara Hacı Bayram Veli Üniversitesi

İktisadi ve İdari Bilimler Fakültesi

Prof. Dr. Sibel ATAN

Ankara Hacı Bayram Veli Üniversitesi

İktisadi ve İdari Bilimler Fakültesi

Prof. Dr. Şenay ÜÇDOĞRUK BİRECIKLII

Dokuz Eylül Üniversitesi

İktisadi ve İdari Bilimler Fakültesi

Prof. Dr. Nurşen CANIKLİĞGLU

Marmara Üniversitesi

Hukuk Fakültesi

Prof. Dr. Elif GÖKÇEARSLAN ÇİFTÇİ

Ankara Üniversitesi

Sağlık Bilimleri Fakültesi

Prof. Dr. Ömer EKMEKÇİ

İstanbul Üniversitesi

Hukuk Fakültesi

Prof. Dr. Zeki ERDUT

Dokuz Eylül Üniversitesi

İktisadi ve İdari Bilimler Fakültesi

Prof. Dr. Atilla GÖKÇE

Ankara Hacı Bayram Veli Üniversitesi

İktisadi ve İdari Bilimler Fakültesi

Prof. Dr. Banu UÇKAN HEKIMLER

Anadolu Üniversitesi

İktisadi ve İdari Bilimler Fakültesi

Prof. Dr. Cemal İYEM

Aydın Adnan Menderes Üniversitesi

Söke İşletme Fakültesi
Prof. Dr. İlknur KILKIS

Bursa Uludağ Üniversitesi

İktisadi ve İdari Bilimler Fakültesi

Prof. Dr. Handan KUMAŞ

Pamukkale Üniversitesi

İktisadi ve İdari Bilimler Fakültesi

Prof. Dr. Umut OMAY

İstanbul Üniversitesi

İktisat Fakültesi

Prof. Dr. Kamil ORHAN

Pamukkale Üniversitesi

İktisadi ve İdari Bilimler Fakültesi

Prof. Dr. Serap PALAZ

Bandırma Onyedi Eylül Üniversitesi

İktisadi ve İdari Bilimler Fakültesi

Prof. Dr. Faruk SAPANCALI

Dokuz Eylül Üniversitesi

İktisadi ve İdari Bilimler Fakültesi

Prof. Dr. Filiz Elmas SARAC

Ankara Hacı Bayram Veli Üniversitesi

İktisadi ve İdari Bilimler Fakültesi

Prof. Dr. Ferda YERDELEN TATOĞLU İstanbul Üniversitesi

İktisat Fakültesi

Prof. Dr. Aysen TOKOL

Bursa Uludağ Üniversitesi

İktisadi ve İdari Bilimler Fakültesi

Prof. Dr. Suat UĞUR

Çanakkale Onsekiz Mart Üniversitesi

Biga İktisadi ve İdari Bilimler Fakültesi

Prof. Dr. Handan YOLSAL

İstanbul Üniversitesi

İktisat Fakültesi

Doç. Dr. Erdem CAM

Ankara Üniversitesi

Siyasal Bilgiler Fakültesi
Doç. Dr. Hamdi EMEÇ

Dokuz Eylül Üniversitesi

İktisadi ve İdari Bilimler Fakültesi

Doç. Dr. Furkan EMIRMAHMUTOĞLU Ankara Hacı Bayram Veli Üniversitesi İktisadi ve İdari Bilimler Fakültesi

Doç. Dr. Aycan HEPSAĞ

İstanbul Üniversitesi

İktisat Fakültesi

Doç. Dr. Recep KAPAR

Muğla Sitkı Koçman Üniversitesi

İktisadi ve İdari Bilimler Fakültesi

Doç. Dr. Serdar KURT

Çanakkale Onsekiz Mart Üniversitesi

Biga İktisadi ve İdari Bilimler Fakültesi

Doç. Dr. Banu METİN

Ankara Hacı Bayram Veli Üniversitesi

İktisadi ve İdari Bilimler Fakültesi

Doç. Dr. Nagihan DURUSOY ÖZTEPE Pamukkale Üniversitesi

İktisadi ve İdari Bilimler Fakültesi

Doç. Dr. Ramazan ŞAHIN

Gazi Üniversitesi

Mühendislik Fakültesi

Doç. Dr. Özgür TOPKAYA

Çanakkale Onsekiz Mart Üniversitesi Biga İktisadi ve İdari Bilimler Fakültesi

Doç. Dr. Özlem YORULMAZ

İstanbul Üniversitesi

İktisat Fakültesi

Dr. Öğr. Üyesi Ömer DORU

Mardin Artuklu Üniversitesi

İktisadi ve İdari Bilimler Fakültesi

Dr. Öğr. Üyesi Özlem GÖKTAŞ

İstanbul Üniversitesi

İktisat Fakültesi

Dr. Cihan Serhat KART

Ankara Üniversitesi

Ayaş Meslek Yüksekokulu 


\section{SAYI DEĞERLENDİRME ISTATISSTIKLERİ}

EVALUATION STATISTICS FOR THIS ISSUE

Toplam gelen makale başvurusu

Yayına kabul edilen makale sayısı

Hakem süreci devam eden makale sayısı

Red edilen makale sayıs

Ön inceleme aşamasında red edilen makale sayısı

Makale kabul oranı
Number of received manuscript

39

Number of accepted manuscript

Under consideration

Rejected after evaluation

Rejected before evaluation

2

Accepted manuscript rate

$\% 35$ 
Araştırma Makalesi - Research Article

\section{Bireysel Emeklilik Sistemine Analitik Bakış: Yoğunlaşma ve Yapısal Kırılma Analizi ${ }^{1}$}

\section{Analytical View of the Individual Pension System: Concentration and Structural Break Analysis}

\author{
Sümeyra KARA* \\ (iD) 0000-0001-6030-5162 \\ Harun Türker KARA** \\ (D) 0000-0003-1613-3572
}

Sosyal Güvenlik Dergisi / Journal of Social Security Cilt: 10 Say1: 2 Y1l: 2020 / Volume: 10 Issue: 2 Year: 2020 Sayfa Aralığı: 333-352/ Pages: 333-352

DOI: $10.32331 /$ sgd.840714

\section{ÖZ}

21. yüzyılda dünya genelinde artan sosyal güvenlik harcamaları ülke ekonomilerinde ciddi bir finansal yük doğurmuştur. Emeklilik sistemlerinin sürdürülebilirliğinin güçleşmesiyle, birçok ülkenin sosyal güvenlik açıklarını azaltmak için çeşitli girişimlerde bulunduğu görülmüştür. Bu kapsamda, Türkiye'de bireysel emeklilik sistemi sosyal güvenlik sisteminin tamamlayıcısı olarak tasarlanmıştır. İçinde bulunduğumuz yüzyılın başında aktif olarak uygulanmaya başlanan sistemde zaman içinde pek çok değişiklik gerçekleşmiştir. Bu çalışma ile dünyada ve Türkiye'de bireysel emeklilik sektörünün gelişimi, Türkiye'de bireysel emeklilik sisteminde yapılan değişiklikler ve bu değişikliklerin piyasa yapısındaki etkileri incelenecek ve bireysel emeklilik sistemindeki yapısal kırılmalar ele alınacaktır. Çalışmanın amacı, bireysel emeklilik sektöründe faaliyet gösteren emeklilik şirketlerine ait Emeklilik Gözetim Merkezi verileri kullanılarak 2003 - 2019 döneminde Türkiye'de bireysel emeklilik piyasasının incelenmesidir. Analiz kısmında, çoklu yapısal kırılma testi kullanılarak bireysel emeklilik sistemindeki çeşitli değişikliklerin yasal, teknolojik, ekonomik ve politik kaynakları ortaya konmuş ve bu durumun piyasanın mikro yapısı üzerindeki etkisi çeşitli piyasa yoğunlaşma endeksleri ile ölçülmüştür.

Anahtar Sözcükler: Emeklilik sistemleri, bireysel emeklilik, piyasa yapısı, yapısal kırılma, yoğunlaşma analizi

\begin{abstract}
In the 21st century, increasing social security expenditures around the world caused serious financial burden on national economies. As the sustainability of pension systems becomes more problematic, it has been observed that many countries have taken various initiatives to reduce social security deficits. In this context, individual pension system in Turkey is designed to complement the social security system. Many changes have been made over the system which was actively implemented at the beginning of this century. In this study, the development of the individual pension sector in Turkey and in the world, the changes made in the individual pension system in Turkey will be examined and the effects of these changes in the structure of markets along with a structural break in the individual pension system will be discussed. The study aims to examine the individual pension market in Turkey between 2003 - 2019 period by using the data of pension companies operating in the individual pension sector from Pension Monitoring Center. In the analysis part, by using multiple structural break test the legal, technological, economic and political sources of various changes in the individual pension system are displayed and the effect of this situation on the micro structure of the market is measured with the various market concentration indices.
\end{abstract}

Keywords: Pension systems, individual pension, market structure, structural break, concentration analysis

Önerilen atıf şekli: Kara, S. ve Kara, H. T. (2020). Bireysel Emeklilik Sistemine Analitik Bakış: Yoğunlaşma ve

Yapısal Kırılma Analizi. Sosyal Güvenlik Dergisi (Journal of Social Security). 10(2). 333-352

Geliş Tarihi/Received: 08/06/2020 • Güncelleme Tarihi/Revised: 23/09/2020 • Kabul Tarihi/Accepted: 16/12/2020

\footnotetext{
* Dr., Türkiye Bilimsel ve Teknolojik Araştırma Kurumu, sumeyrakaratas@gmail.com

** Dr., T.C. Sağlık Bakanlı̆̆ı, haruntkara@gmail.com

1 Bu çalışma, Ufuk Üniversitesi 1. Uluslararası Sosyal Bilimler Kongresinde kabul alan tebliğin genişletilmiş ve güncellenmiş halidir. Yazarların kişisel görüşlerini içermekte olup, aksi belirtilmedikçe kurumsal görüşleri yansitmamaktadır.
} 


\section{GİRIŞ}

Sosyal güvenlik sistemleri ülkede yaşayan kişilere temel gelir güvencesi sağlamayı ve kişilerin sağlıklı yaşam sürmelerine katkı yapmayı hedeflemektedir. Sosyal güvenlik sistemlerinin işleyişinde ülkelerin demografik yapısı ve iş gücü piyasasındaki değişimler ve bu değişimler üzerinde etkili olan sağlık sektöründeki teknolojik ilerleme, doğurganlık oranı, yaşam sürelerinin uzaması ve kayıt dışı çalışanlar gibi unsurlar etkili olmaktadır.

Günümüzde ülkeler ekonomilerinde sosyal güvenlik harcamalarındaki açıkları azaltmak konusunda çok yönlü girişimlerde bulunmaktadır. Dünya genelinde sosyal güvenlik harcamalarının artış eğiliminde olması ülke ekonomilerine ciddi bir finansal yük getirmekte ve emeklilik sistemlerinin sürdürülebilirliğini güçleştirmektedir.

Sosyal güvenlik sistemlerinin sürdürülebilirliğinin güçleşmesi temelde dağıtım esasına dayalı kamu emeklilik sistemlerinden kaynaklanmaktadır. Yaşanan demografik değişimler ve finansal gelişmeler dağıtım esasına dayalı kamu emeklilik sistemlerinin sürdürülebilirliğini güçleştirmiş, yaşanan sıkıntıları aşma noktasında dünya genelinde birçok reform gerçekleştirilmiş ve kamu emeklilik sistemlerini tamamlayıcı unsurlar önem kazanmaya başlamıştır. Bu kapsamda dağıtım esasına dayalı kamu emeklilik sistemlerini tamamlayıcı unsur olarak mesleki emeklilik programlarının yanı sıra bireysel emeklilik programlarının birçok ülkede kullanılması yaygınlaşmıştır (Gökbayrak, 2010: 91 - 92).

Dünyada yaygın olarak kullanılan bireysel emeklilik planları ülkemizde ilk kez 2003 yılında uygulanmaya başlanmıştır. Bireysel emeklilik planı edinen bireyler kendi emekliliğini kendisi planlamakta ve uygulama gönüllülük esasına dayanmaktadır. Katılımcıların birikimleri hisse senedinden altına kadar çok geniş bir yelpazade farklı yatırım enstrumanlarında değerlendirilebilmektedir. Bireysel emeklilik sisteminde katılımcının toplam birikimi, emeklilik dönemi içerisinde düzenli aylıklar halinde alınabildiği gibi emeklilik ile birlikte toplu olarak da çekilebilmektedir. Katılımcı ile emeklilik şirketi arasındaki işleyiş emeklilik sözleşmesi ile belirlenmektedir. Sözleşme içerisinde, bireysel emeklilik sistemine giriş, sistemden ayrılış, ödenecek katkı miktarı ve bu miktarda yapılabilecek değişiklikler, ödemenin yapılış şekli ve emeklilik hükümlerini de içeren çeşitli konularda tarafların hak/yükümlülükleri yer almaktadır. Bu açıdan emeklilik şirketleri bireysel emeklilik sisteminin işleyişindeki temel aktörlerden biridir.

$\mathrm{Bu}$ çalışmada dünyada ve Türkiye'de sosyal güvenlik sisteminde bireysel emeklilik basamağının gelişimi, Türkiye'de bireysel emeklilik sisteminde yapılan değişiklikler ile bu değişikliklerin piyasa yapısındaki etkileri incelenerek, Türkiye'de bireysel emeklilik sistemindeki yoğunlaşma ve yapısal kırılmalar ele alınacaktır. Bu kapsamda çalışma ile Türkiye'deki bireysel emeklilik piyasasında faaliyet gösteren firmaların Emeklilik Gözetim Merkezi tarafından açıklanan 2003 - 2019 yılları arasındaki verileri kullanılarak bireysel emeklilik sektörünün bütüncül olarak incelenmesi ve piyasa yapısının ortaya konulması amaçlanmıştır.

\section{I- DÜNYADA EMEKLILIKK SISTTEMLERI VE BİREYSEL EMEKLILIK PROGRAMLARI}

Sosyal güvenlik harcamalarında yaşanan artışta ülkelerin nüfus ve iş gücü piyasasındaki değişiklikler etkili olmuştur. Bu bağlamda dünya genelinde doğurganlığın azalması ve sağlık alanında yaşanan olumlu gelişmelerin etkisiyle yaşam sürelerinin uzaması sonucunda yaşlı nüfusun önemli ölçüde artması ve kayıt dışı çalışanlar nedeniyle emeklilik sistemlerinin kapsamında bulunan kişi oranının düşmesi bu değişiklikler arasındadır (Miralles, Romero ve Whitehouse, 2012: 12). 
Nüfusun yaşlanması, emeklilik tasarruflarındaki getiri düşüklügü, ekonomik büyüme, oranının düşük düzeyde kalması, istikrarsız iş kariyeri ve çalışan kesimin bir kısmında hakim olan hangi emeklilik sisteminde olursa olsun emeklilik döneminde elde edecekleri gelirin azalacağı, çalışma dönemlerindeki refah seviyelerini sürdürmek için yeterli olmayacağı inancını oluşturmaktadır (OECD, 2018a: 11).

Günümüzde dünyada birçok ülkede yaşlı nüfus oranı toplam nüfus içerisinde artış göstermektedir. Bu kapsamda sosyal güvenlik sistemlerinin ülke ekonomileri açısından finansal bir yük haline gelmesi olasıdır. 20 - 64 yaş arası çalışma çağındaki yüz kişiye düşen 65 yaş ve üstü yaşlı sayısını ifade eden "demografik yaşlılık bağımlılığı oranı" OECD ortalaması 1950 yılında 13,9 iken, 2000'de 22,5'e, 2015 yılında ise 27,9'a yükselmiş; bu oranın 2025 yılında 35,2'ye 2050 yılında ise 53,2'ye ulaşması öngörülmektedir. Yapılan öngörülere göre 2075 yılına gelindiğinde OECD ülkelerinin çoğunda bu oranının 50'yi geçmesi, Yunanistan, İspanya ve Japonya gibi ülkelerde ise 70 'in üzerine çıkacağı görülmektedir. (OECD, 2017a: 122).

Yaşlanmanın hızlanması emeklilik sistemlerine sürekli bir baskı yaratmaktadır. Yaşlanan toplumların zorluklarıyla başa çıkmak, daha düşük net ücret, daha yüksek işsizlik ve/veya emekli maaşı vaatlerinin düşmesine neden olmaktadır. Bu durumda emeklilik yeterliliğini ve finansal sürdürülebilirliği korumak için daha uzun süre çalışmak önemli hale gelmektedir. Bununla birlikte, emeklilik yaşını yükseltmek çoğu zaman zorlu bir reform olarak görülmektedir (OECD, 2019b: 16).

Şekil 1. Normal Emeklilik Yaşı

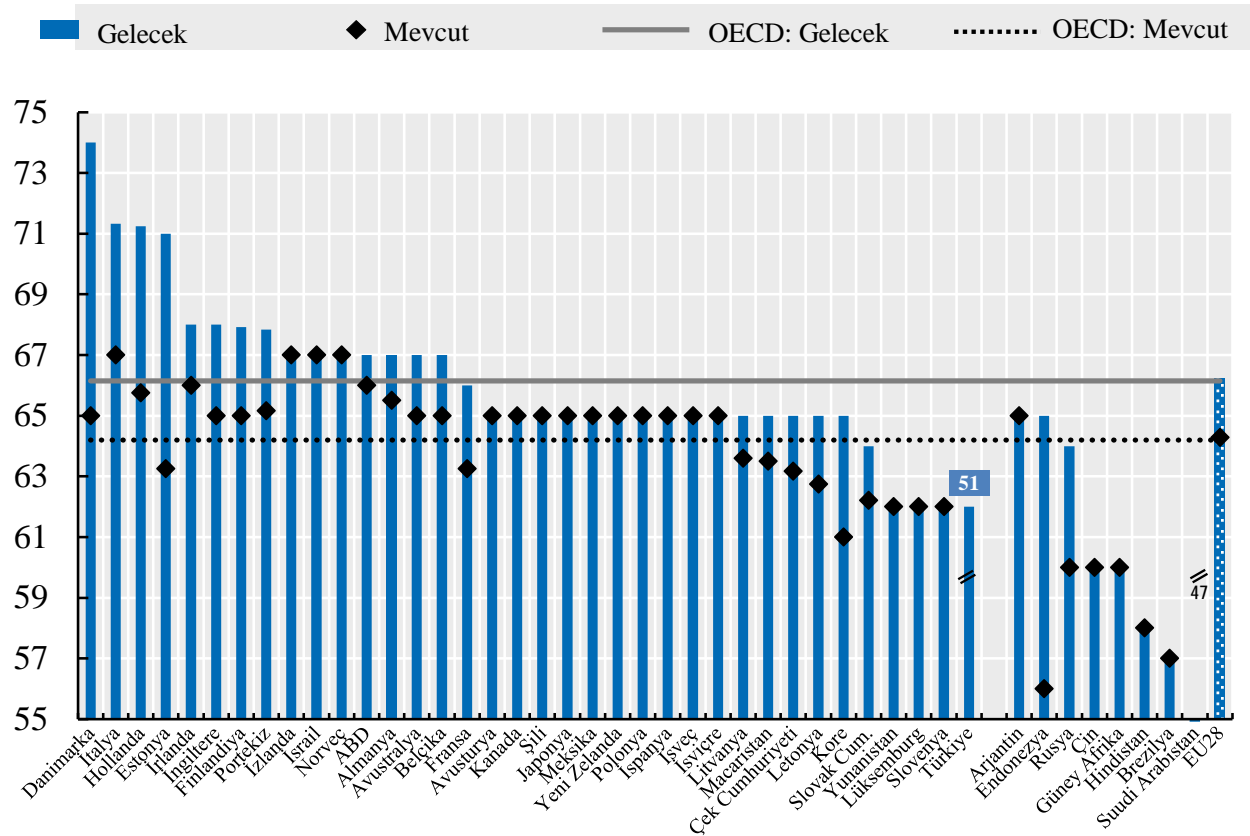

Kaynak: OECD, 2019b: 27

Dünya genelinde yaşam süresi beklentisinin yükselmesi emeklilik yaşını da etkilemiştir. Şekil 1'de erkeklerin 22 yaşından itibaren çalışmaya başlayarak herhangi bir emeklilik bileşeninden ceza almadan emeklilik ödeneğine hak kazandıkları yaş olan normal emeklilik yaşı hesaplamasının, ülkeler ve OECD ortalaması bazında mevcut ve gelecekteki değerlerine 
yer verilmektedir. Şekle göre OECD ülkelerinde normal emeklilik yaşı önemli ölçüde farklılık göstermekle birlikte ülkelerin birçoğunda gelecekteki normal emeklilik yaşı artmaktadir.

2018 yılında normal emeklilik yaşı Türkiye'de erkekler için 51, kadınlar için 48 iken, hem erkekler hem de kadınlar için İzlanda, İtalya ve Norveç'te 67'dir. Mevcut mevzuata göre, gelecekteki normal emeklilik yaşı OECD ülkelerinden sadece Yunanistan, Lüksemburg, Slovak Cumhuriyeti, Slovenya ve Türkiye'de 65 yaşın altında olacak diğerlerinde 65 yaşın üzerinde seyredecektir. Ayrıca, OECD üyesi olmayan tüm G20 ülkelerinde 65 yaş ve altı emeklilik yaşı olacaktır. Suudi Arabistan'da ise normal emeklilik yaşı 47 yaş olup en düşük seviyeye sahip ülkedir (OECD, 2019b: 26 - 27).

Ülkelerin emeklilik sistemleri genel olarak üç ayaklı bir yapıdan oluşmaktadır. Birinci ayakta zorunlu kamu emeklilik sistemleri yer almaktadır. Bu sistemler dağıtım esasına dayanmakta olup ülkede yaşayanlara genel bir koruma sunmaktadır. Bu yolla ülkede sosyal refah yükseltilmektedir. İkinci ayakta fonlama esasına dayanan kamu ya da özel zorunlu tasarrufları sağlayan emeklilik fonları bulunmakta olup genellikle mesleki emeklilik planlarından oluşmaktadır. Bu yolla emeklilik sisteminde kamu emeklilik ayağının yükünün azaltılması ve bireylerin çalışma hayatları sonrasındaki dönemde refah seviyelerini yükseltmek hedeflenmektedir. Üçüncü ayak ise gönüllülük esasına dayalı tasarruf oluşturan özel bireysel emeklilik planlarıdır. Burada amaç bireylerin katkılarıyla oluşan tasarrufların değerlendirilerek emeklilik döneminde bireyin refah seviyesini artırmaktır (OECD, 2017a: 87).

Ülkelerin emeklilik sistemlerinde son ayakta yer alan bireysel emeklilik planları, bireylerin mesleği veya işvereni ile ilişkili değildir. Bireysel emeklilik planları kapsamında bireylerin hakları işlerinden ayrılmaları halinde de sürmekte olup bu planlar genelde belirli katkı ve gönüllülük esasına dayalı olarak oluşturulmakta ve teşvik edilmektedir (Derelioğlu, 2001: 23). Bu planlar sosyal güvenlik sistemlerinin sürdürülebilirliğine katkı sağlamakta ve bireylerin emeklilik döneminde çalışma dönemlerindeki yaşam standartlarının korunmasını güvence altına almayı amaçlamaktadır.

Bireysel emeklilik planları ülke ekonomilerine de çeşitli katkılar sağlamaktadır. Emeklilik fonları birçok ülke için ulusal finansal sistemin derinleşmesi noktasında da önemlidir. Bunlar arasında tasarruf oranlarını, sermaye piyasalarının derinliğini, kamu/özel sektör borçlanma imkanlarını, yatırım araçlarının ve türevlerinin çeşitlenmesini sayabiliriz. Dolayısıyla bireysel emeklilik sistemleri ülke ekonomilerinin büyümesi ve finansal sistemlerinin gelişımine sağladığı katkı açısından önemli kabul edilmektedir (Aggarwal ve Goodell, 2013: 1861).

Yaşanan demografik değişimler ve finansal gelişmeler sosyal güvenlik sistemlerinin sürdürülebilirliği konusunda kuşkulara neden olmuş ve bu kapsamda çeşitli reformlar gerçekleştirilmiştir. Reformlarda her ülke kendi demografik ve işgücü piyasası yapısına uyumlu uygulamayı yürürlüğe koymakta ve demografik değişimler ya da işgücü piyasası göstergelerine bağlı olarak da bu reformları güncelleyebilmektedir. Yapılan reformların ana çıkış noktası dağıtım esasına dayanan kamu emeklilik sistemleri ile ilgili finansal sorunların hafifletilmeye çalışılmasıdır.

Sosyal güvenlik sistemlerinin sürdürülebilirliğini etkileyen unsurlardan biri de finansal krizlerdir. Finansal krizlerin bireysel emeklilik fon varlıkları üzerinde yatırımların değerinin düşmesiyle kısa dönemli birincil ve uzun dönemli ikincil olumsuz etkileri bulunmaktadır (Pino ve Yermo, 2010: 17). Kriz sonrasında yaşanan belirsizlik emeklilik fon varlıkları 
üzerinde büyük ölçüde etkili olmakta, emeklilik yatırımlarının daha düşük riskler içeren muhafazakâr yatırımlara kaymasına neden olmaktadır. Ek olarak kriz sonrası ekonomik koşullardan kaynaklı işsizliğin artması, emeklilik birikimlerini düşürerek emeklilik gelirlerini olumsuz yönde etkileyecektir (Antolín ve Stewart, 2009: 4).

Bu nedenle emeklilik sistemlerinde yapılan reformlarda 2008 krizi de etkili olmuştur. Şekil 2'de görüldüğü gibi 2008 krizi emeklilik fon varlıklarını olumsuz yönde etkilemiştir. 2008 krizi sonrası, 2009 - 2013 döneminde, OECD ülkelerinde emeklilik reformu kapsamında emeklilik sistemlerinin kapsam, finansal yeterlilik, sürdürülebilirlik, çalışma teşvikleri, yönetsel etkinlik, çeşitlendirme ve güvenlik başlıklarında çeşitli düzenlemeler yapılmıştır (OECD, 2013: 19). Bu düzenlemelerin etkileriyle emeklilik fon varlıklarında yaşanan artış Şekil 2'de gösterilmektedir.

Şekil 2. OECD Ülkelerindeki Emeklilik Fon Varliklarl: 2006 - 2018 (Trilyon \$)

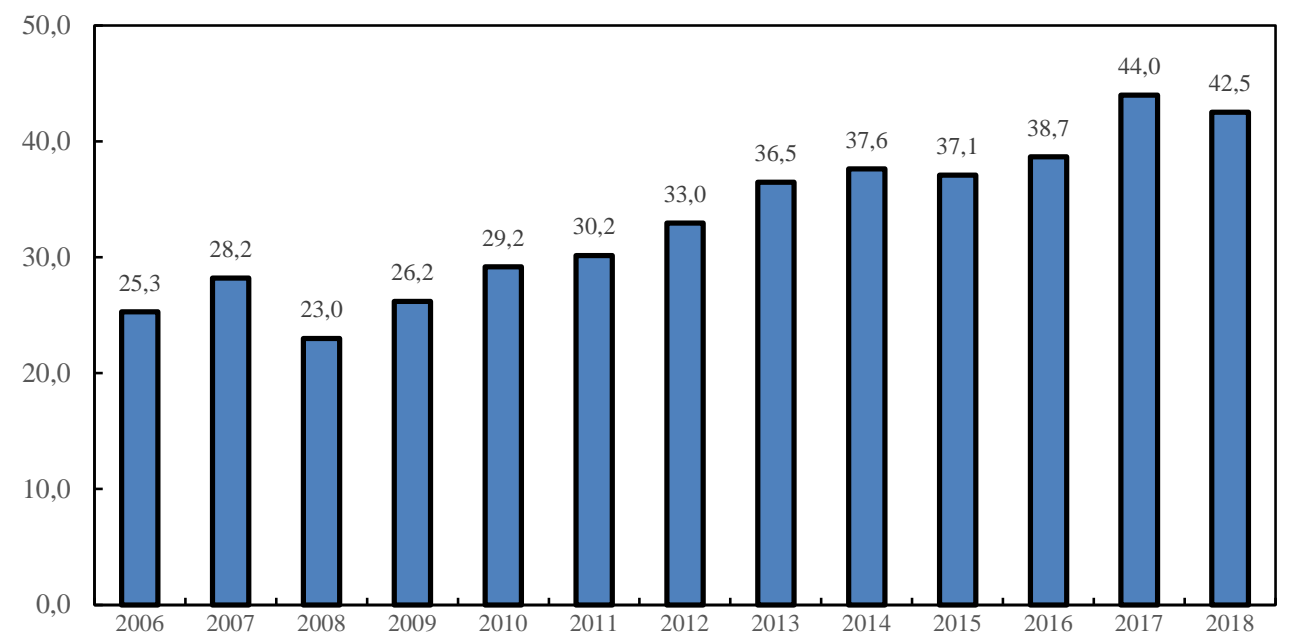

Kaynak: OECD 2019a: 15; OECD 2017b: 11

2008 krizi sonrası birçok ülkede gerçekleşen emeklilik reformları bütçe baskısının artmasının etkisiyle ağırlıklı olarak emeklilik sistemlerinin finansal sürdürülebilirliğine odaklanmış ve emeklilik geliri yeterliliğini geliştirmeyi hedeflemiştir. Bu kapsamda yapılan reformlar aşağıda sıralanmıştır (OECD, 2014: 54):

- Ekonomik krizden şiddetli etkilenen bazı ülkeler emeklilik sistemlerinin finansal sürdürülebilirliğini geliştirmeye yönelik sosyal haklarda nominal kesintiler gerçekleştirmiştir.

- OECD ülkelerinin büyük kısmı emeklilik geliri veya kamunun belirlenmiş katkı programlarına yapılan katkılar üzerindeki vergileri artırmıştır.

- Harcamaları azaltmaya yönelik olarak emeklilik haklarının endekslenmesinde azaltmaya ya da ertelemeye başvurulmuştur.

- Birçok ülke, yasal emeklilik yaşını yükselterek, katkı süresini genişletmiş, daha uzun süre etkili çalışanlar için yeterliliği korurken katkı tabanını genişletmiştir.

- İş teşvikleri, erken emekliliğe daha sıkı erişim ve/veya çalışmak için artan finansal teşvikler yoluyla güçlendirilmiştir. Bazı ülkelerde bunun aksine uzun kariyeri olan 
çalışanların emeklilik yaşı düşürülerek işgücü piyasasından erken yaşta ayrılmaları teşvik edilmiştir.

- Verimlilik kazançları sağlamak için emeklilik yönetim maliyetlerini azaltmaya yönelik önlemler yaygın olarak kullanılmıştır.

- Emeklilik sistemi gelirlerini artırmak için bazı ülkelerde, zorunlu emeklilik haklarının kapsamına daha önce hariç tutulan (serbest çalışanlar gibi) işgücü grupları eklenmiştir. Bazı ülkeler yeni haklar uygulamaya koymuş, birçok ülke ise daha yüksek emeklilik hakları elde etmenin ve yeterlilik endişelerini gidermenin bir yolu olarak çalışma hayatını uzatmıştır.

- Çeşitliliği artırma ve özel emeklilik birikimlerini korumaya yönelik politikalar krizden sonra yaygınlaşmıştır.

- Bazı ülkeler belirli katkı esasına dayalı fonlanan emeklilik programlarında zorunlu katkı paylarını artırmıştır.

Emeklilik sistemlerinde yapılan reformlarda 2015 - 2017 döneminde, nüfus yaşlanmasının öngörülen hızda artması, çalışma çağında daha yüksek eşitsizlik ve işin değişen doğası göz önüne alındığında, emeklilik sistemlerinin finansal sürdürülebilirliği ve emeklilik geliri yeterliliği konusundaki endişelerin devam etmesine neden olmuştur. Finansal sürdürülebilirliği ele alan geçmiş reformlar, birçok ülkede emeklilik maaşlarının düşmesine neden olmuştur (OECD, 2017a: 11). 2017 - 2019 dönemindeki emeklilik reformlarının çoğu, emeklilik maaşı almak için yaş gereksinimlerinin gevşetilmesine, birinci kademe emeklilik maaşları dâhil emeklilik maaşlarının artırılmasına, emeklilik kapsamının geniş̧letilmesine veya özel tasarrufların teşvik edilmesine odaklanmıştır (OECD, 2019b: 15). Bu anlamda kamu emeklilik sistemlerini tamamlayıcı rol üstlenen bireysel emeklilik programlarının önemi daha da artmaktadır.

Tamamlayıcı olarak kabul edilen uygulamalar her zaman gönüllülük esasına dayanmayabilir. Bazı ülkelerde emeklilik planlarının zorunlu olduğu görülmektedir. Bu kapsamda bireyler, bazı ülkelerde birkaç planın üyesi olabilmekte, bu planlar zorunlu, yarı-zorunlu ya da gönüllülük esasına dayalı uygulanmaktadır.

Norveç'de işverenlerin çalışanlara zorunlu olarak oluşturduğu planlar, Danimarka ve Letonya'da çalışanların devlet tarafından fonlanan emeklilik planına katkı yapması ile Şili ve Meksika'da çalışanların kendi seçtikleri özel bir emeklilik fonuna katkıda bulunması zorunlu uygulamalara örnek olarak gösterilmektedir (OECD, 2018b: 12).

Zorunlu bireysel emeklilik hesapları ilk kez Şili'de uygulandığında çok yaygın değilken sonrasında daha fazla ülkede zorunlu uygulamalar yapılmıştır (Holzmann, 2012: 3). Günümüzde bireysel emeklilik planlarının sosyal güvenlik sistemini tamamlayıcı uygulamaları daha yaygın olmakla birlikte, bazı ülkelerde emeklilik maaşlarını ekonomik ve demografik gelişmelere göre ayarlamak ve yaşlılık yoksulluğunu önlemek için güvenlik ağlarını güçlendirme önlemleri alarak otomatik katılım mekanizmaları başlatılmıştır (OECD, 2018a: 11).

Gerçekleştirilen reformların da olumlu etkisiyle emeklilik fonlarının birçok ülkede hızlı bir ivme ile büyüdüğü görülmektedir. OECD ülkelerinde fonlanmış özel emeklilik birikimlerinin ülkelerin gayri safi yurtiçi hasılalarına (GSYIH) oranlarının 2002 ve 2017 yıllarındaki değişimi Şekil 3'te gösterilmektedir. 
Şekil 3. Fonlanmış Özel Emeklilik Fon Varlıklarının GSYIH'ya Oranı (\%):(2002 - 2017)

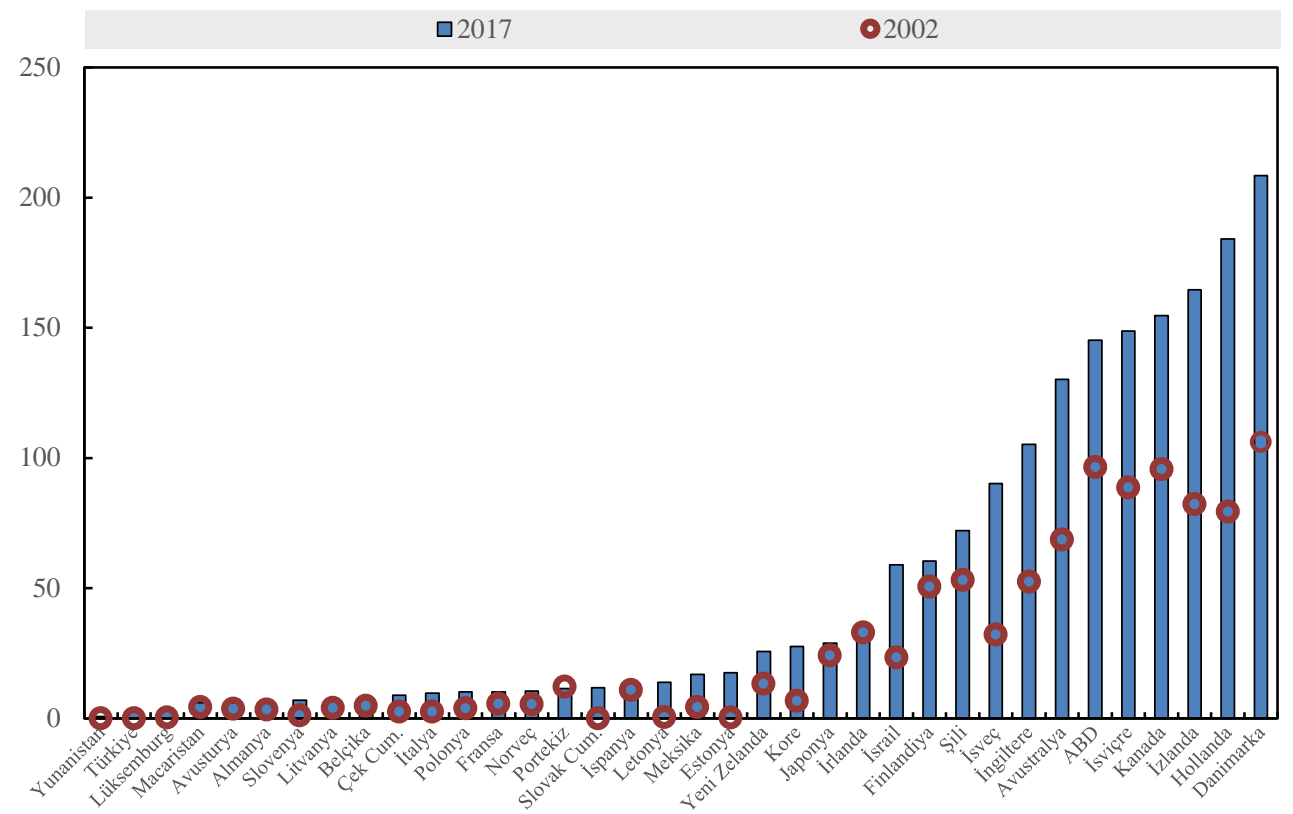

Kaynak: OECD, 2018a: 21

Şekil 3 incelendiğinde ülkelerdeki emeklilik fonlarının GSYIH'ya oranının son on beş yılda arttı̆g1 görülmektedir. Danimarka'da 2002 yılında emeklilik fon varlıklarının ülke GSYIH'sından daha fazla olduğu 2017 yılında ise ülke GSYIH'sının iki katını aştığı görülmektedir. 2002 yılında sadece Danimarka'da emeklilik fon varlıkları ülke GSYIH'sını geçmiş iken, 2017 yılında yedi ülkede emeklilik fonlarının ülke GSYIH'sından yüksek olduğu dikkat çekmektedir. Bu oran Türkiye'de \% 2,6 ile Yunanistan'ın ardından en düşük seviyede seyretmektedir.

Genel olarak dünyada yaşanan demografik değişimler ve finansal krizler nedeniyle sosyal güvenlik sistemlerinin sürdürülebilirliği noktasında sorunlar yaşanmaktadır. Bu kapsamda dağıtım esasına dayanan kamu emeklilik basamağının çalışanlara minimum ihtiyaçlarına yetecek bir refah seviyesi sağlamasının benimsendiği ve bu basamağı destekleyici tedbirlerin teşvik edildiği dikkat çekmektedir. Öte yandan bazı ülkelerde zorunlu uygulamaları içeren daha sert önlemler alındığı; tamamlayıcı tedbirleri yaygınlaştırmak için Türkiye'nin de aralarında olduğu bazı ülkelerde otomatik katılım mekanizmaları geliştirildiği görülmektedir. Bütün bu gelişmeler ekseninde yapılan reformlar ve düzenlemelerin etkisiyle dünya genelinde bireysel emeklilik planları yaygınlaşmıştır.

\section{II- TÜRKIYE'DE BIREYSEL EMEKLILIIK SISTEMI}

Dünya genelinde olduğu gibi ülkemizde de doğurganlığın azalması ve sağlık alanında yaşanan gelişmelerin etkisiyle yaşam sürelerinin uzaması ve yaşlı nüfusun artmasıyla sosyal güvenlik sisteminin sürdürülebilirliği konusunda sorunlar yaşanmaya başlamıştır. $\mathrm{Bu}$ anlamda emeklilik yaşının mevzuat değişikliği öncesi düşük seviyede seyretmesi de sosyal güvenlik sistemindeki yükleri artırmıştır. 
Türk sosyal güvenlik sistemindeki yükleri hafifletmek amacıyla çeşitli reformlar yapılmıştır. Kamu sosyal sigorta rejimlerinin birbirine yakınlaştırılması 1999 yılında çıkarılan 4447 sayılı Kanunla gerçekleştirilmiş ve emeklilik sisteminde yaş, aylık bağlama oranı ve aylık hesaplama yöntemi gibi parametrik değişiklikler yapılmıştır. Bu adımı 2006 yılında sosyal güvenlik kurumlarının tek çatı altında toplanması ve 2008 yılında Genel Sağlık Sigortası sisteminin kurulması ile farklı emeklilik uygulamalarının hak ve yükümlülüklerinin aynı çatı altında birleştirilmesi izlemiştir (Kalkınma Bakanlığı, 2018a: 2).

Türkiye demografik yaşlılık bağımlılığı oranı bakımından birçok OECD ülkesinden çok daha iyi durumdadır. Ancak ülkemizdeki oran incelendiğinde yaşanan demografik değişimden diğer ülkeler gibi ülkemizin de etkilendiği görülmektedir. Türkiye'de demografik yaşlilık bağımlılığı oranı 1950 yılında 6,5 iken, 2000'de 11,4'e, 2015 yılında ise 13,4'e yükselmiştir. Oranın 2050 yılında 36,2'ye 2075 yılında ise 54,8'e ulaşması öngörülmektedir (OECD, 2017a: 123).

Türkiye'de 2006 yılında gerçekleştirilen düzenleme ile emekli olma yaşı kademeli olarak artırılmış, 2048 yılı itibarıyla kadınlarda 58 yaştan 65 yaşa, erkeklerde ise 60 yaştan 65 yaşa çıkarılmıştır (OECD, 2013: 39). Bu düzenlemeden önce emeklilik hakkı ülkemizde diğer ülkelere göre daha erken yaşta elde edildiğinden sosyal güvenlik sistemindeki yük artmıştır.

Sosyal güvenlik sisteminin uzun vadede finansal sürdürülebilirliğinin sağlanması için 5510 Sosyal Sigortalar ve Genel Sağlık Sigortası Kanunu ile aylık bağlama oranlarında düzenleme yapılmıştır. Bu durum, sigorta primlerinin çalışanların gerçek ücretler üzerinden bildirilmesi, bireylerin aktif çalışma dönemlerinin uzamasının teşvik edilmesi ve bireysel emeklilik tasarrufların artırılması konularını önemli hale getirmiştir (Kalkınma Bakanlığı, 2018b: 38).

Türkiye'de de dünyadakine benzer şekilde sosyal güvenlik sisteminin uzun vadede finansal sürdürülebilirliğinin sağlanması noktasında bireysel emeklilik planlarının etkili olabileceği değerlendirilmiş ve bireysel emeklilik sistemi kurularak teşvik edilmiştir.

Sosyal güvenlik sisteminin finansmanını kolaylaştırmak, emekli maaşları üzerindeki baskıyı rahatlatmak ve emeklilik yaşının yükseltilmesiyle ileri yaşlarda işgücü piyasasında yer alacak kişilerin refah seviyesini korumak amacıyla bireysel emeklilik sisteminin geliştirilmesi için önemli adımlar atılmıştır. Bu kapsamda 2001 tarihinde mevzuatı oluşturulan bireysel emeklilik sisteminin ilk katılımcıları 2003 yılında alınmıştır. Sisteme giriş isteğe bağlı olup sistemden aylık bağlanabilmesi için en az 10 yıl sistemde kalmak ve 56 yaş şartlarını sağlamak gerekmektedir.

Kanunda Türkiye'de uygulanan bireysel emeklilik sisteminin kamu sosyal güvenlik sisteminin tamamlayıcısı olarak işlev görmesi ve bireylerin emeklillik tasarruflarının değerlendirilmesini sağlamasını amaçladığı vurgulanmaktadır. Sistem gönüllülük esasına dayalı olup belirli katkı esasına göre yürütülmektedir.

Bireysel emeklilik sisteminin uygulanması ülkemizde eskiye dayanmamaktadır. Dünya uygulamalarına göre nispeten yeni sayılan bireysel emeklilik sisteminin Türkiye'de gelişimi üç ana dönemde incelenebilir (Akgiray, Peksevim ve Sener, 2016: 2; Kara ve Yıldız, 2016: 42 - 43; Emeklilik Gözetim Merkezi, 2016: 7; www.egm.org.tr);

- 2002 - 2012 Dönemi: Dünya örneklerine benzer şekilde dağıtım esasına dayalı kamu sosyal güvenlik ayağını tamamlayıcı nitelikte katılımcıların emeklilik birikimlerinin yatırıma yönlendirilmesi amacıyla kurgulanan bireysel emeklilik sistemi ile katılımcıların emeklilik döneminde refah seviyelerinin yükseltilmesi ve finansal 
sisteme uzun dönemli kaynak yaratılarak ülke ekonomisine katkı sağlanması öngörülmüştür. $\mathrm{Bu}$ dönemde bireysel emeklilik sisteminin teşvik edilmesi amacıyla vergi teşviki uygulaması benimsenmiştir. Gelir vergisi mükellefi olmayan kişiler vergi teşvikinden yararlanamadığından bu dönemde sistemin kapsamı daha dar bir katılımc1 kitlesine hitap etmiştir.

- 2013 - 2015 Dönemi: Bireysel emeklilik sistemine katılım konusunda istenilen seviyeye ulaşılamayınca 2012 yılında sistemde köklü bazı değişiklikler yapılmıştır. Bu kapsamda 2013 yılında bireysel emeklilik sistemine olan katılımı artırmak amaciyla sistemde bireylerin ödediği katkı miktarının vergi matrahından düşürülmesi uygulamasına son verilerek, sistemde uzun vadeli kalmayı teşvik eden \% 25 devlet katkısı uygulamasına başlanmıştır. $\mathrm{Bu}$ yolla sadece gelir vergisine tabi olanların yararlandığı bireysel emeklilik sistemi, 18 yaşını doldurmuş, çalışan, çalışmayan her kesimin sistemden yararlanabileceği bir yapı haline gelmiştir. Katılımcı sistemden 3 yıldan önce ayrılırsa devlet katkısı alamamaktadır. Sistemden 3-6 yıl arası katkı ödedikten sonra ayrılması durumunda \% 15, 6-10 yıl arası katkı ödedikten sonra ayrılması durumunda \% 35 ve 10 yıl katkı ödedikten sonra ayrılması durumunda \% 60 oranında devlet katkısı elde etmektedir. Öte yandan emekliliğe hak kazandıktan sonra sistemden ayrılan veya ölüm/daimi sakatlık nedeniyle sistemden ayrılan katılımcılar devlet katkısının tamamını elde etmektedir.

Buna ek olarak sisteme kurumsal düzeyde katılım artışı, sistemdeki maliyetlerin bireyler ve emeklilik şirketleri açısından azaltılması ve fon getirilerinin artırılmasına yönelik düzenlemeler yapılarak iyileştirme yönünde adımlar atılmıştır. Tüm bu düzenlemelere rağmen emeklilik fonlarının payı istenilen seviyelere ulaşamamıştır. Bu kapsamda 2015 yılı içinde bazı değişikliklere gidilmiştir.

- 2016 - 2019: 2015 yılının son döneminde açıklanan ekonomik reform programında, bireysel emeklilik sisteminde bazı değişiklikler yapılmıştır. Otomatik katılım uygulamasının bireysel emeklilik sistemine entegre edilmesi için başlatılan pilot uygulama 2015 yılı içerisinde başarıyla tamamlanmış, bazı ülkelerde uygulanan otomatik katılım sisteminin Türkiye'de de uygulanmasına karar verilmiştir. Otomatik katılım sisteminde bireylerin işe başlar başlamaz sisteme girmesi sağlanmakta olup, bu yolla ABD, İngiltere, Yeni Zelanda, Avustralya gibi ülkelerde emeklilik fonlarının ülke ekonomisindeki payında artış sağlanmıştır.

Bireysel emeklilik sistemine katılımı teşvik etmek amacıyla işveren aracılığıyla bireysel emeklilik sistemine zorunlu katılımı öngören otomatik katılım sistemi 2017 yılında uygulamaya konulmuştur. Uygulama ile kırk beş yaş altı çalışanlar, bireysel emeklilik sistemine kademeli olarak girmiştir. Bu geçişte özel sektörde işyeri büyüklüğü dikkate alınmıştır. Otomatik katılım uygulamasında, prime esas kazancın \% 3 'ü oranında çalışan katkı payı ödenmekte olup, söz konusu katkı payına \% 25 oranında devlet katkısı teşviki verilmesi ve emeklilik hakkını en az 10 yıllık gelir sigortası alarak kullanmayı seçen katılımcıya birikiminin \% 5'i kadar ekstra devlet katkısı verilmesi amaçlanmıştır. Ayrıca katılımcıya otomatik katılım ile dahil olduğu sistemden ayrılmaması durumunda, tek seferlik 1.000 TL devlet katkısı verilmiştir. Otomatik katılım ile uzun dönemde sistemdeki katılımcı sayısının artması ve emeklilik tasarruflarının yükseltilmesi amaçlanmaktadır.

Ayrıca 2015 yılında bireysel emeklilik sistemindeki katılımcı sayısını etkileyen iki düzenleme gerçekleştirilmiştir. Kesintilerdeki iyileştirme ve yıllık gelir sigortası uygulamasıdır. Kesintilerin azaltılması tüm katılımcıları iyi yönde etkilemiştir. Yııllık 
gelir sigortası ise bireysel emeklilik planlarının gerçek bir emeklilik aracı gibi kullanmasına imkan sağlamıştır.

Hazine ve Maliye Bakanlığı tarafından 2019 yılında yayımlanan "Yeni Ekonomi Programı: Yapısal Dönüşüm Adımları" adındaki politika kararlarında bireysel emeklilik sistemi ve kıdem tazminati reformuna ilişkin maddeler bulunmaktadır. Bunlar arasında bireysel emeklilik sisteminin yeniden yapılandırılması, tüm paydaşların katılımı ile kıdem tazminatı reform'nun gerçekleştirilmesi, kıdem tazminati reformu ile bireysel emeklilik sisteminin entegrasyonu, 2020 yılından itibaren her yıl otomatik katılım sistemi ve gönüllü bireysel emeklilik sisteminde en az 100 milyar TL fon biriktirilmesi, beş yıl içinde milli gelirin \% 10'unu aşan bir toplam fon büyüklüğüne ulaşılması hususları yer almaktadır (Hazine ve Maliye Bakanlığı, 2019b).

2019-2023 dönemi için yapılan planlamaların yer aldığı On Birinci Kalkınma Planında da bireysel emeklilik sisteminde yeni düzenlemeler yapılması öngörülmektedir. $\mathrm{Bu}$ düzenlemeler arasında; bireysel emeklilik sistemi katılımcı sayısının sistemde geçirilen süre ve fon miktarını artıracak şekilde geliştirilmesi, bireysel emeklilik sistemindeki mevcut devlet desteklerinin genç kesime cazip gelecek şekilde yaşa göre farklılaştırılması, sağlık, evlilik, eğitim, mülk sahibi olma gibi ihtiyaçlar nedeniyle bireylere sistemden çıkmadan birikimlerinin bir kısmını çekme olanağı tanınması, otomatik katılım sisteminin sistemdeki kalış süresi ve fon tutarını artıracak şekilde yeniden düzenlenmesi ve bireysel hesaplara dayalı kurulacak kıdem tazminatı fonu ile entegre edilmesi yer almaktadır. Bu doğrultuda bireysel emeklilik sisteminin önümüzdeki dönemde daha da fazla katılımcıya ulaşması beklenmektedir.

Şekil 4. Katılımcılara İlişkin Fon ve Katkı Payı Tutarları

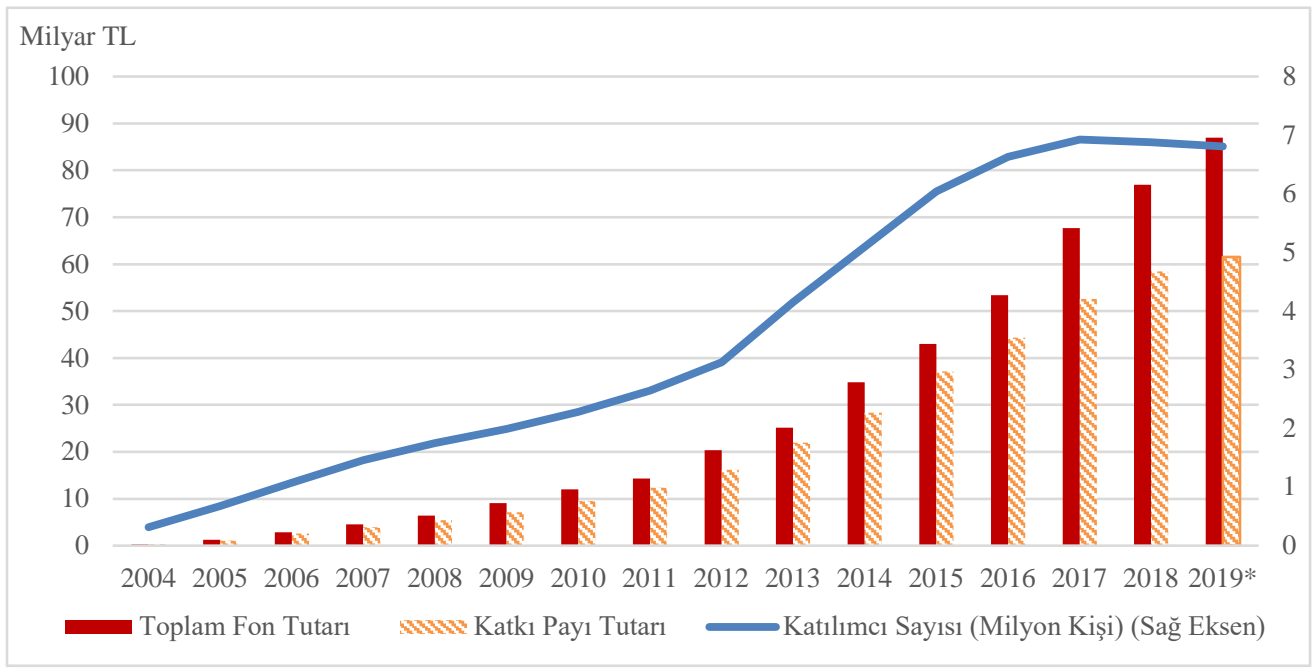

Kaynak: Emeklilik Gözetim Merkezi, 2019

*Haziran sonu itibarıla

Bireysel emeklilik sistemi ana göstergelerinin değişimi incelendiğinde sisteme ilgide artış görülmektedir. Şekil 4'te 2004 - 2019 yılları arasında sistemdeki katılımcı sayısı, katılımcıların toplam fon tutarı ve katkı payı tutarlarında düzenli artış dikkat çekmektedir. $\mathrm{Bu}$ artışta kamu emeklilik sistemindeki emekli olma yaşının yükseltilmesi, sisteme girişi teşvik etmek için vergi avantajı ve devlet katkısı gibi uygulamaların benimsenmesi de etkili 
olmuştur. Katılımcı sayısında 2013 yılında yaşanan yükselmede ise 2012 yılında gerçekleştirilen düzenlemeler ve devlet katkısı uygulaması etkili olmuştur.

Bireysel emeklilik sistemindeki katılımcı sayısı 2018 yılı sonunda 6,9 milyona, katılımcılara ait fon tutarı da devlet katkısı ile birlikte 88,4 milyar TL'ye yükselmiştir. Ek olarak 2017 yılında bireysel emeklilik sisteminde otomatik katılım uygulamasına başlanmıştır. Bu durum katılımcı sayısı ve toplam fon büyüklügü miktarını olumlu yönde etkilemiştir. Otomatik katılım uygulamasında 2018 yıl sonu itibarıla 5 milyona yakın katılımcı sisteme dahil edilmiş ve fon büyüklüğü toplamı 4,7 milyar TL'ye ulaşmıştır (Hazine ve Maliye Bakanlığı, 2019a: 65).

Emeklilik şirketleri bireysel emeklilik sisteminde önemli bir aktör olarak faaliyet göstermekte olup 4632 sayılı Kanunun sekizinci maddesinde, bireysel emeklilik sisteminde faaliyet göstermek amacıyla emeklilik alanında ruhsat almış şirket olarak tanımlanmaktadır. Tablo 1'de 2019 yılı Haziran sonunda bireysel emeklilik sistemindeki emeklilik şirketlerinin bilgileri bulunmaktadır.

Tablo 1. Bireysel Emeklilik Şirketlerine İlişkin Göstergeler (2019 Haziran)

\begin{tabular}{|c|c|c|c|c|c|}
\hline Emeklilik Şirketi & $\begin{array}{l}\text { Katılımcı } \\
\text { Sayısı }\end{array}$ & Fon Tutarı (TL) & $\begin{array}{l}\text { Katkı Payı } \\
\text { Tutarı (TL) }\end{array}$ & $\begin{array}{l}\text { Emekli } \\
\text { Sayısı }\end{array}$ & $\begin{array}{l}\text { Sözleşme } \\
\text { Sayısı }\end{array}$ \\
\hline Aegon Emeklilik ve Hayat & 37.836 & 128.173.724 & 82.992 .666 & 727 & 43.028 \\
\hline Allianz Hayat ve Emeklilik & 95.504 & 2.771.715.397 & 1.857.282.921 & 4.100 & 111.435 \\
\hline Allianz Yaşam ve Emeklilik & 731.710 & 11.993.495.919 & 8.060 .899 .390 & 12.393 & 876.220 \\
\hline Anadolu Hayat Emeklilik & 1.096 .033 & 16.078 .212 .868 & 11.419 .620 .054 & 25.794 & 1.287 .079 \\
\hline Avivasa Emeklilik ve Hayat & 793.836 & 16.653.997.576 & 11.604 .920 .673 & 20.215 & 1.008 .593 \\
\hline Axa Hayat ve Emeklilik & 34.154 & 417.496 .551 & 307.954 .120 & 73 & 43.413 \\
\hline Bereket Emeklilik ve Hayat & 94.592 & 355.407 .182 & 240.124 .481 & 38 & 99.399 \\
\hline $\begin{array}{l}\text { BNP Paribas Cardif } \\
\text { Emeklilik }\end{array}$ & 182.438 & 2.235.913.376 & 1.578.686.592 & 2.632 & 220.282 \\
\hline $\begin{array}{l}\text { Cigna Finans Emeklilik ve } \\
\text { Hayat }\end{array}$ & 84.662 & 685.410 .548 & 509.336 .159 & 223 & 90.660 \\
\hline Fiba Emeklilik ve Hayat & 91.737 & 1.601.074.099 & 1.114.861.609 & 1.582 & 108.690 \\
\hline Garanti Emeklilik ve Hayat & 1.114 .168 & 12.473.184.069 & 8.826 .041 .347 & 15.142 & 1.185 .384 \\
\hline Groupama Hayat* & & & & 2.974 & \\
\hline Halk Hayat ve Emeklilik & 560.751 & 3.963.874.609 & 3.089.395.212 & 364 & 640.362 \\
\hline Katılım Emeklilik ve Hayat & 251.185 & 1.429.349.548 & 1.151.029.969 & 111 & 358.448 \\
\hline Metlife Emeklilik ve Hayat & 183.751 & 1.574 .441 .433 & 1.222 .849 .227 & 513 & 202.714 \\
\hline NN Hayat ve Emeklilik & 255.518 & 3.128.131.754 & 2.216 .641 .537 & 5.564 & 300.636 \\
\hline Vakıf Emeklilik ve Hayat & 546.040 & 7.115.497.272 & 4.847.384.094 & 9.284 & 783.475 \\
\hline Ziraat Hayat ve Emeklilik & 656.234 & 4.388 .873 .228 & 3.406 .623 .250 & 1.363 & 738.402 \\
\hline Sektör Toplamı & 6.810 .149 & 86.994.249.153 & 61.536.643.301 & 103.092 & 8.098.220 \\
\hline
\end{tabular}

Kaynak: Emeklilik Gözetim Merkezi, 2019

* Groupama Hayat'ın yürürlükteki sözleşmelerinin Fiba Emeklilik ve Hayat'a portföy devri ile aktarılması nedeni ile 30.03.2018 tarihi itibari ile Groupama Hayat'ın "Emekli Olan Katılımcı Sayısı" hariç tüm verileri sıfırlanmıştır. 
Emeklilik şirketinin ticaret unvanında "emeklilik" ibaresinin bulunması zorunlu tutulmuş, kuruluş izin şartları Kanunla belirlenmiştir. Ayrıca şirketin emeklilik branşı dışında başka bir branşta faaliyet göstermesi halinde her bir branşa ait hesapların ayrı tutulması istenmiştir. Dolayısıyla bireysel emeklilik sisteminde emeklilik şirketlerinin faaliyetleri sıkı kurallara bağlanmıştır.

Emeklilik yatırım fonu, emeklilik şirketi tarafından emeklilik sözleşmesi çerçevesinde tahsil edilen ve katılımcılar adına bireysel emeklilik hesaplarında izlenen katkıların değerlendirilmesi amacıyla oluşturulan bir yatırım fonudur. Tüzel kişiliği olmayan fon 4632 sayılı kanununda belirtilen amaçlar dışında kullanılamaz ve kurulamaz; emeklilik şirketleri tarafından kurulur ve portföy yönetim şirketleri tarafından yönetilir.

Emeklilik şirketleri sadece emeklilik planları satma ve bireylerden katkı toplama konusunda yetkilendirilmiştir. Şirketlerin fonları yönetmelerine izin verilmediğinden, katılımcıların katkılarını yönetmek için bir portföy yönetim şirketi seçmeleri gerekmektedir ve sektörde tekelci yoğunlaşma ile potansiyel yönetişim sorunlarını önlemek için mevzuatla çeşitli kurallar konulmuştur (Peksevim ve Akgiray, 2019: 33).

Şekil 5. Türkiye'de Emeklilik Şirketi Sayıları (2004 - 2019)

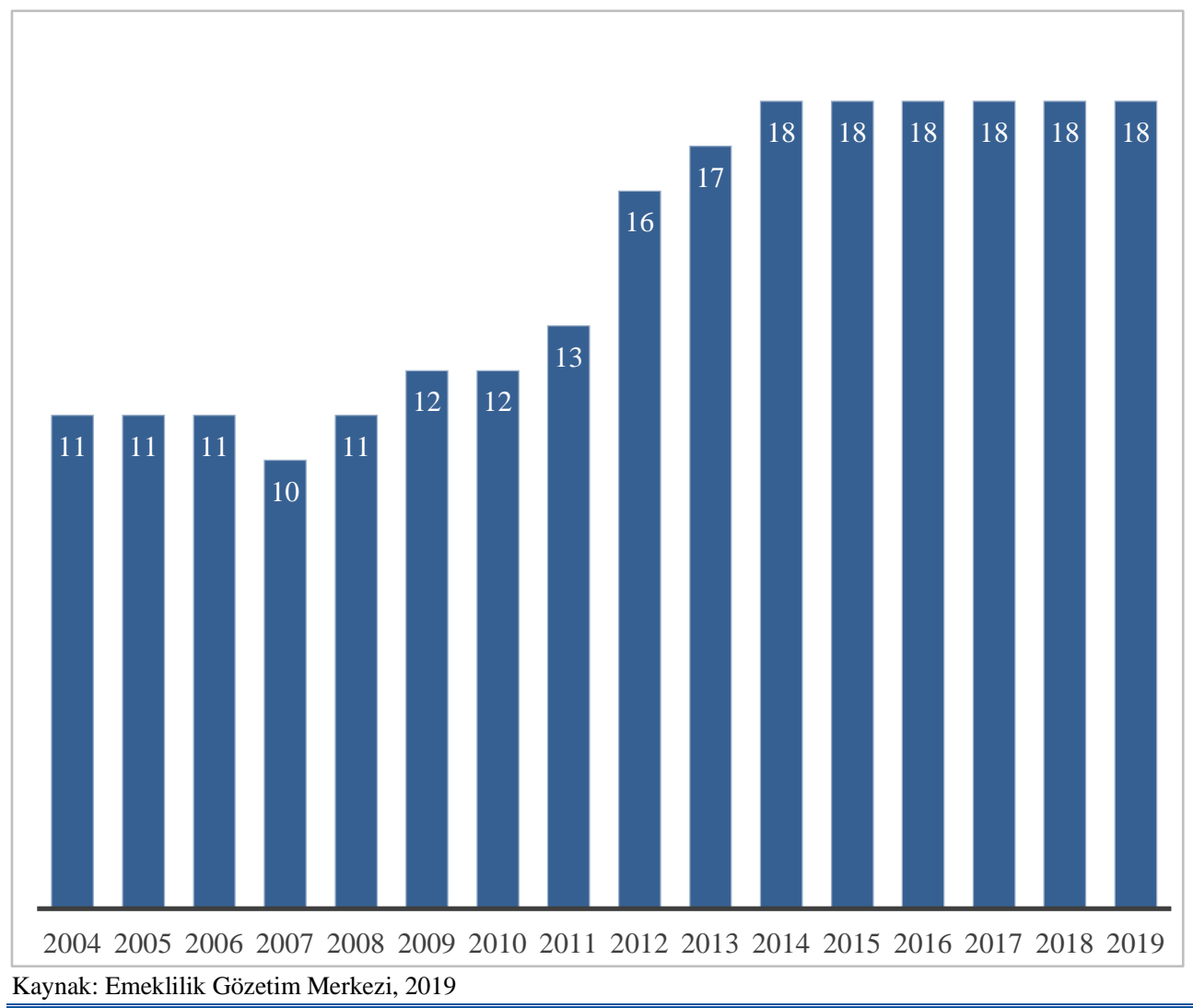

Türkiye'de 2019 Eylül ayı sonu itibarıyla 18 emeklilik şirketi ve 410 emeklilik yatırım fonu bulunmaktadır. Türkiye'de bireysel emeklilik sisteminde bulunan emeklilik şirketi ve emeklilik yatırım fonu sayılarına ilişsin bilgiler Şekil 5 ve Şekil 6'da sunulmuştur. 


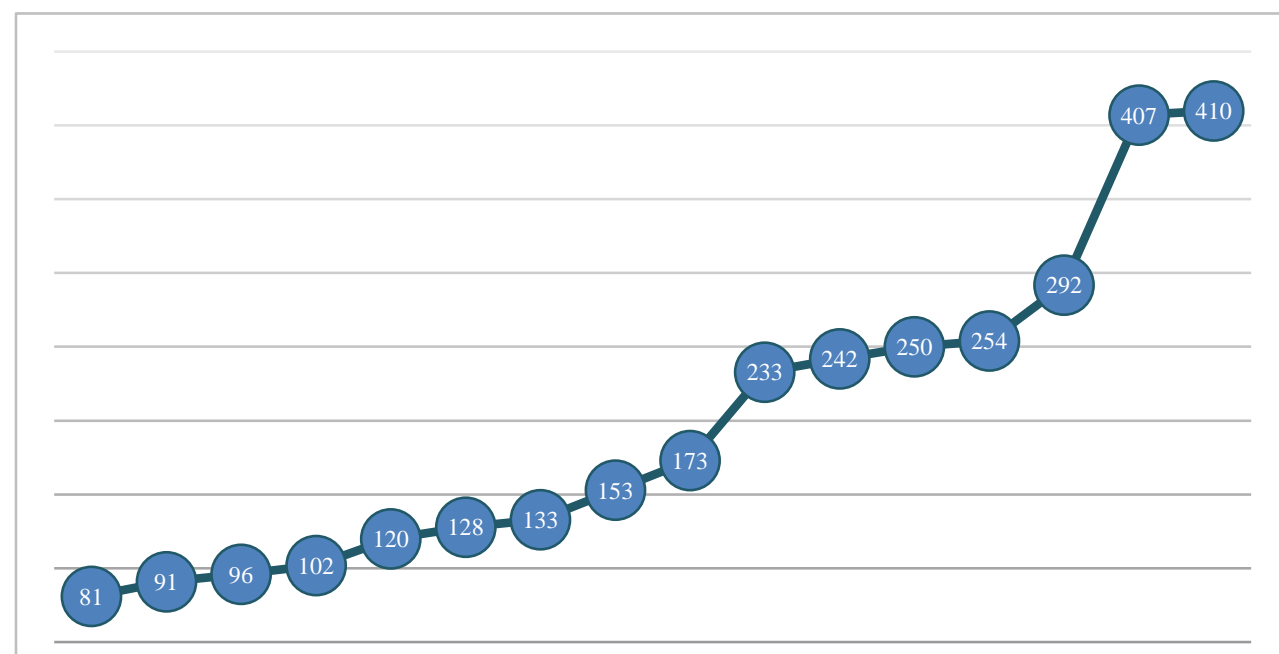

2004200520062007200820092010201120122013201420152016201720182019

Kaynak: Emeklilik Gözetim Merkezi 2004 - 2012 yılları Bireysel Emeklilik Sistemi Yıllık Gelişim Raporları; Türkiye Sermaye Piyasaları Birliği, 2019.

Bilanço büyüklükleri incelendiğinde emeklilik yatırım fonlarının finans sektörü genel toplamı içindeki oranının 2018 yılında \% 2,07 olduğu görülmektedir (Hazine ve Maliye Bakanlığı, 2019a: 3). Bu oran diğer ülke örneklerinin gerisindedir. Bu durum bireysel emeklilik sisteminin Türkiye'de büyüme potansiyelinin yüksek olduğunun bir göstergesi olarak değerlendirilebilir. Bireysel emeklilik sisteminde otomatik katılım uygulamasının başlamasıyla ülkemizde de bireysel emeklilik sisteminin kapsama oranının artması ve emeklilik yatırım fonlarının finans sektörünün genel toplamı içindeki payının yükselmesi beklenmektedir.

\section{III- AMPİRIK ÇALIŞMA}

Çalışmanın bu bölümünde bireysel emeklilik sistemindeki piyasa yapısı incelenecektir. $\mathrm{Bu}$ bağlamda öncelikle sektördeki yoğunlaşma oranı farklı parametreler ile hesaplanacak, devamında ise yapısal kırılma analizi gerçekleştirilecektir.

\subsection{Piyasa Yoğunlaşması Analizi}

Firmaların etkinliği ve kârlılı̆̆ı, alıcı ve satıcıların tercihleri gibi pek çok unsurun anlaşılması piyasa yapısının belirlenmesi ile kolaylaşmaktadır (Ildırar ve Kıral, 2018: 94). Piyasa yapısını değerlendirmek açısından yoğunlaşma kavramı ve yoğunlaşma endeksleri önemlidir. Yoğunlaşma, piyasa yapısını sayısal olarak ölçüp sektörel işleyişiyi anlamayı kolaylaştırmaktadır (OECD, 2018c: 4). Bu bağlamda, ülkemizdeki bireysel emeklilik sisteminin sektörel yapısının anlaşılması amacıyla yoğunlaşma analizi gerçekleştirilmiştir. Analiz kapsamında bireysel emeklilik sistemine üye kaydedilmeye başlandığ 2003 yılı son çeyreğinden 2019 yılının ilk yarısı arasındaki dönemi kapsayacak şekilde Emeklilik Gözetim Merkezinden sağlanan çeyreklik dönemler halinde katkı payı tutarları verisi kullanılmıştır.

Piyasa yoğunlaşmasını ölçmek amacıyla çeşitli yoğunlaşma endekslerinden faydalanılmaktadır. Bu kapsamda kullanılan en önemli endekslerden biri Herfindahl- 
Hirschman (HH) endeksidir. Endeks, Hirschman (1945) ve Herfindahl (1950) tarafindan yapılan birbirinden bağımsız çalışmalara dayanmaktadır (aktaran Ildırar ve Kıral, 2018: 98). Herfindahl-Hirschman endeksi aşağıdaki şekilde formülize edilmektedir:

$$
H H I=\sum_{i=1}^{k} s_{i}^{2}
$$

- $\quad$ HHI: Herfindahl-Hirschman endeksi

- $\mathrm{S}_{\mathrm{i}}$ : İlgili şirketin yüzde olarak hesap edilmiş piyasa pay1

- $\quad$ i ve $\mathrm{k}$ : Piyasadaki şirket sayısı

Herfindahl-Hirschman endeks değerinin Amerika Birleşik Devletleri Adalet Bakanlığı ve Federal Ticaret Komisyonu tarafından 2010 yılında yayımlanan rehberde de belirtildiği üzere, 1500'den küçük olması "yoğunlaşmamış piyasaları"; 1500 ile 2500 arasında değer alması "düşük yoğunlaşmış piyasaları" ve 2500'den büyük değer alması ise "yoğunlaşmış piyasaları" göstermektedir. Bununla birlikte, Herfindahl-Hirschman endeksinde bütün şirketler endeks hesabına katılmakta ve büyük şirketler piyasa paylarının kareleri alındığı için daha büyük bir ağırlık katsayısına sahip olmaktadır. Bu durumun bir sonucu olarak, ilgili sektördeki firma sayısı arttıkça endeks yeni firma girişlerine duyarsız kalmaktadır.

Şekil 7. Herfindahl-Hirschman Endeksi

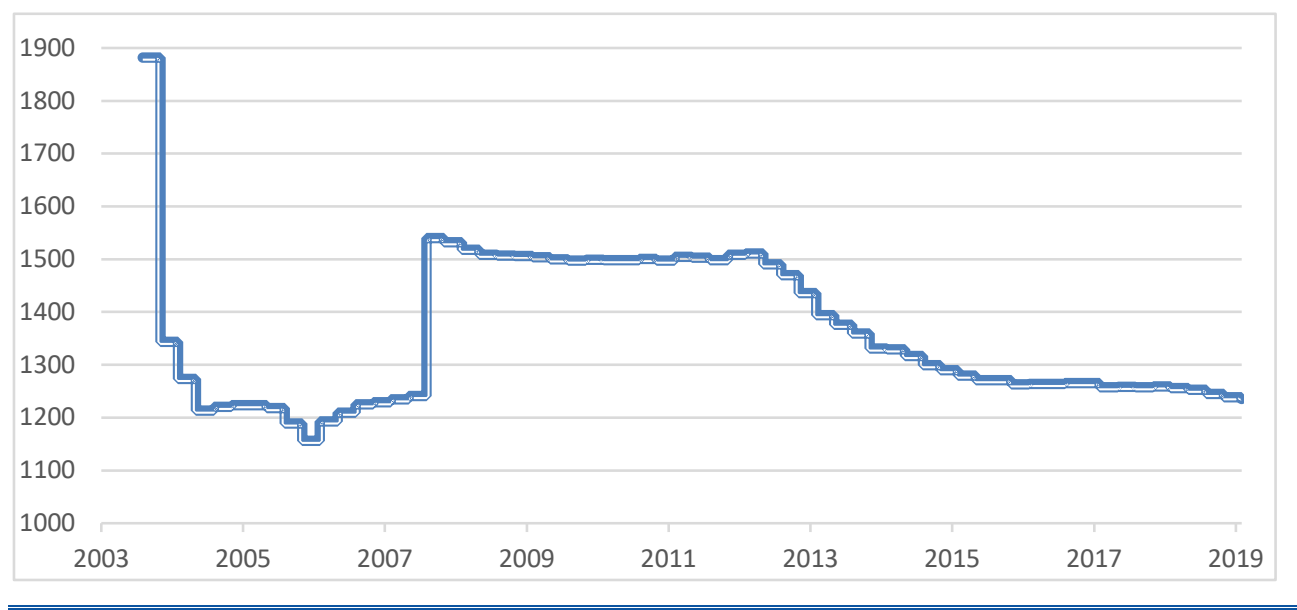

Ülkemizde bireysel emeklilik uygulamasının başından 2019 yılı ilk yarısını kapsayacak şekilde hesaplanan Herfindahl-Hirschman endeksi Şekil 7'de gösterilmektedir. Buna göre endeks, ortalama olarak 1356 değerini almış ve 139 puanlık bir standart sapma göstermiştir. Bununla birlikte endeksin minimum değeri 2006 yılının ilk çeyreğinde 1156, maksimum değeri ise 2003 yılı son çeyreğinde 1882 'dir. Analiz döneminde azalma eğilimi gösteren endeks, dönem içerisinde piyasa yoğunlaşmasının azaldığını ve rekabetçi yapının geliştiğini ifade etmektedir. Herfindahl-Hirschman endeksi ile yapılan değerlendirmelerde genel olarak endeks değerinin 1500'ün altında olması rekabetçi piyasa yapısının yaşandığını, bir başka ifadeyle sektörel olarak yoğunlaşma yaşanmadığını ifade etmektedir.

Bireysel emeklilik sisteminde katkı payları bağlamında yoğunlaşma zaman içinde azalmakta, sektördeki rekabet artmaktadır. Yoğunlaşmadaki bu değişimin nedenleri ise yapısal kırılma testleri ile analiz edilecektir.

Çalışma kapsamında Herfindahl-Hirschman endeksinin daha kapsamlı yorumlanmasını sağlamak üzere Kwoka (1977) tarafından geliştirilen hakimiyet endeksi kullanılmıştır. 
Kwoka endeksi imalat sanayinde hakimiyete odaklanmış olsa da bankacılık gibi çeşitli sektörlerde uygulanmış ve Herfindahl-Hirschman endeksini destekleyici olarak kullanılmıştır (Mutluer Kurul, 2011: 2).

Piyasada eşitsizlik olup olmadığına odaklanan bir endeks olan Kwoka endeksi değerinin azalması ilgili sektörde eşitsizlik/hakimiyet durumunun azaldığını göstermektedir. Bir başka ifadeyle endeks, yoğunlaşma ve eşitsizlik/hakimiyet durumunun birlikte ele alınmasına olanak sağlamakta ve Herfindahl-Hirschman endeksinin aksine büyük firmaların ağırlı̆̆ının azalmasına yol açmaktadır. Kwoka endeksi aşağıdaki şekilde formülize edilmektedir:

$$
K H=\sum_{i=1}^{n-1}\left(p_{(i)}-p_{(i+1)}\right)^{2}
$$

- $\quad$ KH: Kwoka Hakimiyet Endeksi

- $\quad \mathrm{p}_{\mathrm{i}}$ : İlgili şirketin yüzde olarak hesap edilmiş piyasa payı

- $\quad$ i ve n : Piyasadaki şirket sayısı; endeksin hesaplanmasında şirketlerin pazar payları büyükten küçüğe sıralanmalıdır.

Şekil 8. Herfindahl-Hirschman Endeksi ve Kwoka Endeksi

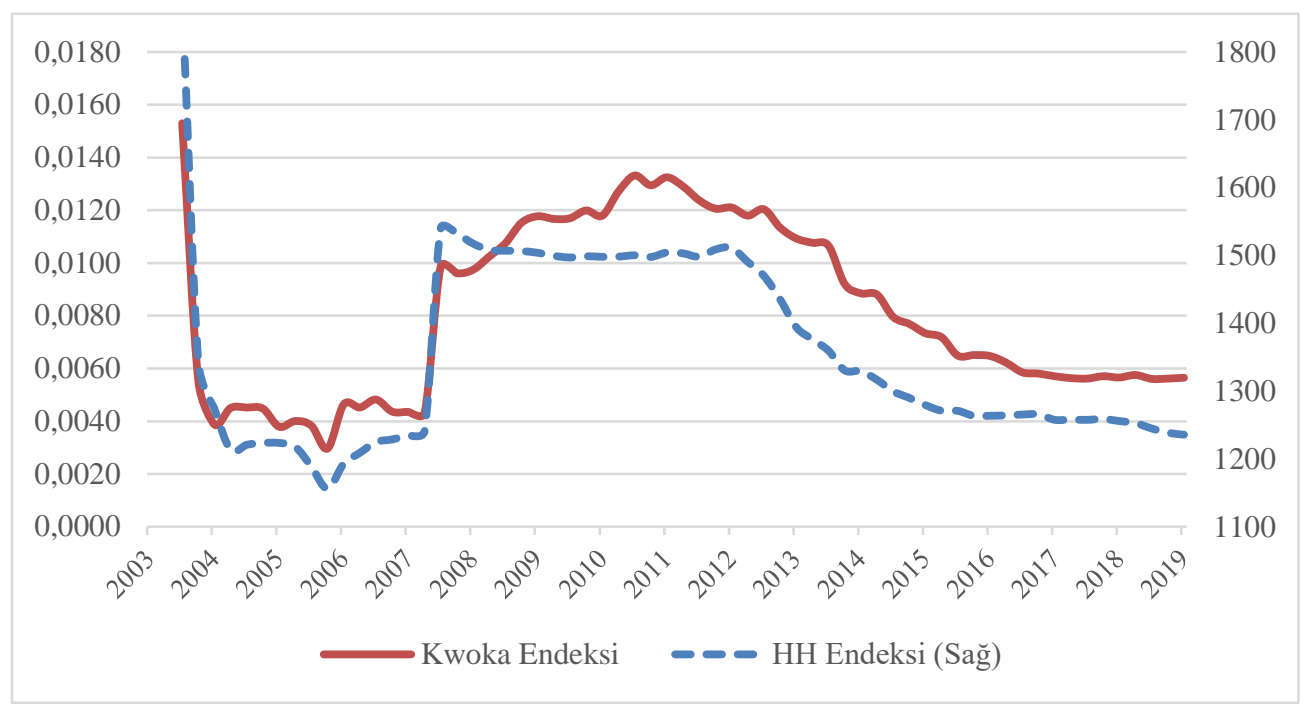

Kwoka endeksi hesaplanırken etkilerin baz puan olarak değelendirilebilmesi amacıya 0 ile 1 arasındaki değerler kullanılmıştır. Kwoka endeksi ve Herfindahl-Hirschman endeksi Şekil 8'de birlikte görülmektedir. Tüm dönem boyunca ortalama olarak 0,0082 değerini alan Kwoka endeksinin dönem içindeki standart sapması 0,0033 olarak hesaplanmıştır. Bununla birlikte, Kwoka endeksinin minimum değeri 2006 yılının ilk çeyreğinde 0,0030, maksimum değeri ise 2003 y1lı son çeyreğinde 0,0153 'dür. Kwoka endeksinin minimum ve maksimum değerlerini gördüğü dönem Herfindahl-Hirschman endeksi ile aynı olup, endeks HerfindahlHirschman endeksi gibi azalış eğilimi göstermektedir. Buna göre, Herfindahl-Hirschman endeksi ile ölçülen yoğunlaşmanın azaldığı dönemlerde Kwoka endeksi azalmakta ve piyasa eşitsizliği (hakimiyet) genel olarak azalmaktadır.

Piyasa yoğunlaşmasını ölçmek amacıyla kullanılan bir başka yol ise Türkiye İstatistik Kurumu (TÜIKK, 2016) tarafından da kullanılan M - Firma Yoğunlaşma (CRM) yöntemidir. $\mathrm{Bu}$ yöntemde şirketlerin pazar büyükleri sıralanan ilk $\mathrm{M}$ firmanın sektörden aldığı toplam 
pay hesaplanarak değerlendirmelerde bulunulur. TÜİK yaklaşımında ilk dört şirketin pazar payı değerlendirilerek CR4 analizi yapılmaktadır. Bu analize göre, CR4 değeri otuzdan küçük ise "düşük derecede yoğunlaşma"; otuz ve üzerinde ancak elliden küçükse "orta derecede yoğunlaşma"; elli ya da elliden yüksek ancak yetmişten küçükse "yüksek derecede yoğunlaşma"; yetmiş ve üzerinde ise "çok yüksek derecede yoğunlaşma" olarak değerlendirilmektedir.

Şekil 9. Herfindahl-Hirschman Endeksi ve CR4 Endeksi

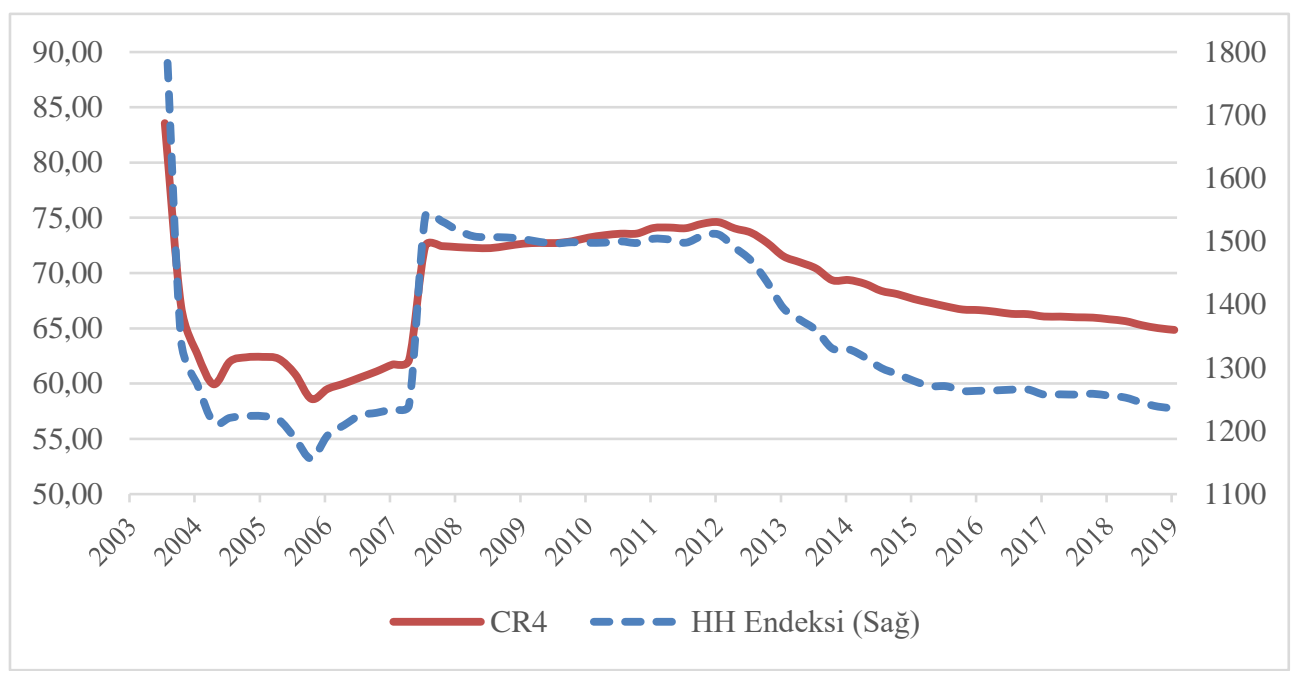

CR4 endeksi ve Herfindahl-Hirschman endeksi Şekil 9'da birlikte görülmektedir. Tüm dönem boyunca ortalama olarak 68 değerini alan CR4 endeksinin dönem içindeki standart sapması ise 5 olarak hesaplanmıştır. Ortalama olarak hesaplanan 68 değeri TÜIKK yaklaşımına göre yüksek derecede yoğunlaşmayı ifade etmekte ve Herfindahl-Hirschman endeksinin yoğunlaşmamış piyasa ifadesi ile uyuşmamaktadır. Diğer taraftan, CR4 endeksi minimum değerini 59 ile 2006 yılının ilk çeyreğinde, maksimum değerini ise 84 ile 2003 yılı son çeyreğinde görmüştür. Endeksin minimum ve maksimum değerlerini gördüğü dönem Herfindahl-Hirschman endeksi ve Kwoka endeksi ile aynı olup, CR4 endeksi de her iki endeks gibi azalış eğilimi göstermektedir. $\mathrm{Bu}$ nedenle, CR4 endeksinin ifade ettiği yoğunlaşmanın ilk 4 firmanın sektörel açıdan baskın olması ile ilişkili olduğu, tüm firmalar dikkate alındığında ise yoğunlaşmanın azaldığ 1 ve rekabetçi yapının korunabildiği değerlendirilmektedir. Genel olarak sektörde faaliyet gösteren şirket sayısının az olması CR4 endeks değerinin yüksek çıkmasında etkili olmuştur.

Tablo 2. Endeksler Arasindaki Korelasyon

\begin{tabular}{lccc}
\hline & $\begin{array}{c}\text { HH } \\
\text { Endeksi }\end{array}$ & CR4 & $\begin{array}{c}\text { Kwoka } \\
\text { Endeksi }\end{array}$ \\
\hline $\begin{array}{l}\text { HH } \\
\text { Endeksi }\end{array}$ & 1,0000 & 0,9422 & 0,9194 \\
\hline CR4 & 0,9422 & 1,0000 & 0,9579 \\
\hline $\begin{array}{l}\text { Kwoka } \\
\text { Endeksi }\end{array}$ & 0,9194 & 0,9579 & 1,0000 \\
\hline
\end{tabular}


Her üç endeks değeri kıyaslandığında ise yukarıdaki grafiksel gösterimi destekleyecek şekilde yüksek korelasyon olduğu görülmektedir. Tablo 2'de gösterilen korelasyon değerlerine göre en yüksek korelasyon CR4 ve Kwoka Endeksi arasında 0,9579 ile gözlemlenmektedir. Diğer taraftan en düşük korelasyon ise 0,9194 ile Herfindahl-Hirschman endeksi ve Kwoka Endeksi arasında görülmektedir.

\subsection{Yapısal Kırılmalar ve Bireysel Emeklilik Sektörünün Gelişimi}

Bireysel emeklilik sistemi, ülkemizin tasarruf açığını etkileyerek makroekonomik dengelere olumlu katkı vermesi ve kamu emeklilik sistemini destekleyerek kamu harcama yükünü desteklemesi öngörülen bir sistemdir. Sistem, bu yönüyle değerlendirildiğinde yapısal değişikliklere oldukça duyarlıdır. Bu çerçevede, çoklu yapısal kırılma testleri ile yaklaşık yirmi yıllık geçmişi olan bireysel emeklilik sistemimizde, sistemin fon büyüklüğüne etki eden yapısal değişiklikler incelenmiştir.

Bireysel emeklilik sistemindeki katkı payı tutarlarındaki yoğunlaşma serisindeki yapısal kırılma ölçülürken endeksler arasındaki yüksek korelasyon dikkate alınarak sadece Herfindahl-Hirschman endeksi kullanılmış ve çoklu yapısal kırılma testi uygulanırken Bai (1997), Bai ve Perron (1998), Bai ve Perron (2003) tarafindan geliştirilen yöntem tercih edilmiştir. Bununla birlikte, serideki varyans sorununun çözülmesi amacıyla White-Hinkey düzeltmesi yapılmıştır. Bu testin tercih edilmesindeki temel neden yapısal kırılma analizinin doğrudan birim kök ya da eşbütünleşme analizine ihtiyaç duymadan yapılmasına olanak sağlamasıdır.

Söz konusu yaklaşım kesin sayısı ve tarihi bilinmeyen çok sayıdaki yapısal kırılmanın belirlenmesi için kullanılmaktadır. Bai (1997) yaklaşımı "ardışık test prosedürü" olarak adlandırılmakta ve öncelikle tüm dönemde parametre durağanlığına ilişkin boş hipotez test edilmektedir. Tüm dönem için parametre durağanlığını kabul eden boş hipotezin reddedilmesi halinde ana örneklem (tüm dönem) iki ayrı örnekleme bölünmekte ve bölünmüş örneklemler için kırılma tarihleri saptanmaktadır. Bu test prosedürü alt örneklemlerde durağanlığa ilişkin boş hipotezin reddedildiği tüm tarihlere uygulanarak, boş hipotezin reddedilmediği örneklemler bulununcaya kadar sürdürülmektedir (EViews, 2019).

Tablo 3. Herfindahl-Hirschman Endeksindeki Yapısal Kırllmaların Tarihleri

\begin{tabular}{|c|c|c|c|}
\hline \multicolumn{2}{|c|}{ Ardışık F İstatistiği Tanımlı Kırılmalar: } & \multicolumn{2}{|c|}{3} \\
\hline Kırılma Testi & F-İstatistiği & $\begin{array}{l}\text { Ölçeklendirilmi F- } \\
\text { Istatistiği }\end{array}$ & Kritik Değger** \\
\hline 0 vs. $1^{*}$ & 27.31843 & 27.31843 & 8.58 \\
\hline 1 vs. $2^{*}$ & 26.1205 & 26.1205 & 10.13 \\
\hline 2 vs. $3^{*}$ & 19.14143 & 19.14143 & 11.14 \\
\hline 3 vs. 4 & 8.475958 & 8.475958 & 11.83 \\
\hline \multicolumn{4}{|c|}{ Kırılma Tarihleri } \\
\hline & Ardışık & \multicolumn{2}{|c|}{ Yinelemeli } \\
\hline 1 & 2014Q1 & \multicolumn{2}{|c|}{ 2007Q4 } \\
\hline 2 & $2007 \mathrm{Q} 4$ & \multicolumn{2}{|c|}{ 2013Q2 } \\
\hline 3 & 2016Q2 & \multicolumn{2}{|c|}{ 2016Q2 } \\
\hline \multicolumn{4}{|c|}{$\begin{array}{l}\text { *0,05 düzeyinde anlamlı } \\
* * \text { Bai-Perron (Econometric Journal, 2003) kritik değerleri. }\end{array}$} \\
\hline
\end{tabular}

Yapısal kırılmaları tarihlerini gösteren Tablo 3'teki test sonuçlarına göre ardışık olarak 0, 1, 2 yapısal kırılma olduğuna ilişkin test istatistikleri F-istatistiği ve Ölçeklendirilmiş Fistatistiği kritik değerden büyük olduğu için reddedilmiş, 3 yapısal kırılma olduğu Fistatistiği ve ölçeklendirilmiş F-istatistiği kritik değerden küçük olduğu için kabul edilmiştir. 
Bu kapsamda ardışık yaklaşıma göre 2007 yılının son çeyreğinde, 2014 yılının ilk çeyreğinde ve 2016 yılının ikinci çeyreğinde yapısal kırılma saptanmıştır.

Analiz sonuçlarına göre, üç temel yapısal kırılmanın sektörel eğilimler ile uyumlu olduğu görülmektedir. Bu yapısal kırılmalardan ilki 2007 yılının sonunda küresel kriz sonucunda global likidite koşullarının değişmesiyle yaşanmıştır. Bu kırılmada kriz ile yeniden şekil kazanan küresel finansal mimari ve fon hareketlerinin etkili olduğu söylenebilir. İkinci yapısal kırılma 2014 yılının başında gerçekleşmiştir. Bu kırılmada bireysel emeklilik sisteminde yapılan hukuki düzenlemeler ve 2013 yılında devlet katkısı uygulamasının başlamasının etkili olduğu söylenebilir. İlgili test sonucuna göre bulunan üçüncü yapısal kırılma ise 2016 yılında yaşanmıştır. Bu kırılmada 2015 yılındaki bireysel emeklilik sistemi hukuki düzenlemeleri ile otomatik katılım uygulamasının Türkiye'de başlatılmasına ilişkin çalışmalar ve uygulama öncesinde katılımcıların tercihlerinde yaşanan değişimlerin etkili olduğu düşünülmektedir. Söz konusu yapısal kırılmalar Şekil 10'da kesikli çizgiler ile gösterilmektedir.

Şekil 10. Herfindahl-Hirschman Endeksi ve Yapısal Kırılmalar

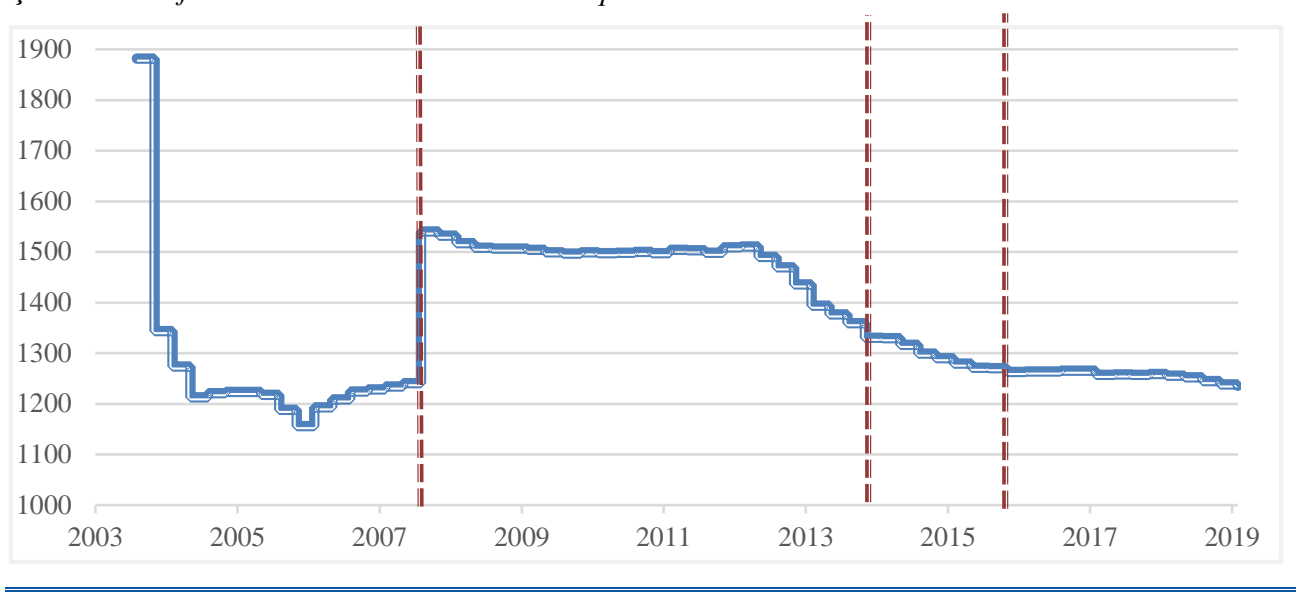

Bireysel emeklilik sisteminin ülkemizdeki gelişimi incelendiğinde yapısal dönüşümlerin, şirket sayısı gibi sektörün mikro yapısına ilişkin hususlardan kaynaklı olmadığ yapılabilmektedir. Örneğin 2014 yılından bu yana faaliyet gösteren şirket sayısı aynı kalmasına rağmen iki adet yapısal kırılma saptanmıştır. Sonuç olarak, sektörel yoğunlaşmada görülen yapısal kırılmaların, küresel gelişmeler ve sektörün bütününü etkileyen makro düzenlemeler kaynaklı olduğu değerlendirilmektedir.

\section{SONUÇ}

Günümüzde ülkeler, nüfus yaşlanmasının tetiklediği zorluklar nedeniyle emeklilik sistemlerinin finansal sürdürülebilirliğini iyileştirmek için birçok reform gerçekleştirmiştir. $\mathrm{Bu}$ reformlar arasında sistemik ve parametrik değişiklikleri içeren farklı uygulamalar bulunmaktadır. Emeklilik sistemlerinde, emeklilik maaşlarının kazançlarla daha sıkı bağlantılı hale gelmesiyle bireyselleşme artmış ve tamamlayıcı emeklilik unsurları ön plana çıkmıştır.

Nüfusun yaşlanması ülkemizde de emeklilik sisteminin finansal sürdürülebilirliğinin dünya örneklerine benzer şekilde değişeceğine işaret etmektedir. Bu değişime ek olarak emeklilik hakkının diğer ülkelere göre erken yaşta elde edilmesi ve emeklilik yaşı konusunda yapılan 
düzenlemelerin etkilerinin uzun dönemli olması sosyal güvenlik sistemindeki yükü artırmaktadır.

$\mathrm{Bu}$ nedenle dünyada olduğu gibi ülkemizde de emeklilik sisteminde reformlar yapılması gündeme gelmiş ve bireysel emeklilik sistemi sosyal güvenlik sistemini tamamlayıcı nitelikte tasarlanmıştır. Türkiye'deki bireysel emeklilik sistemini analitik olarak değerlendirmeyi amaçlayan bu çalışma ile sistemin başlangıcından 2019 yılı ilk yarısına kadar olan değişiklikler ele alınmış, sistem küresel örnekler ile karşılaştırılmıştır. Sektördeki rekabet yapısını farklı ölçütler ile inceleyen bu çalışmanın en önemli katkısı zaman içinde yoğunlaşmada yaşanan değişikliklerin ana nedenlerinin ortaya çıkarılması ve yapılan değişikliklerin rekabet yapısına etkisini göstermesidir.

Çalışmanın bulgularına göre, sektörde rekabet artma, bir başka ifadeyle yoğunluk düşme eğilimindedir; küresel ekonomik kriz ile başlayan küresel fon akışlarındaki belirsizlik söz konusu dönemde yoğunlaşmayı artırsa da düşme eğilimi dönem boyunca devam etmiştir. Yapısal kırılmalarda devlet katkısı ve otomatik katılım uygulamasının önemli olduğu görülmektedir. Bu çerçevede, 2007 yılının son çeyreğindeki yapısal kırılmanın küresel ekonomik kriz ile, 2014 yılının ilk çeyreği ve 2016 yılının ikinci çeyreğindeki yapısal kırılmaların ise ağırlıklı olarak devlet katkısı ve otomatik katılım gibi sektörel bazlı uygulamaların etkisi ile gerçekleştiği değerlendirilmektedir.

Yapısal kırılmaların tespit edilebilmesi, karar alıcıların öngörü yapabilme olanağını genişletmektedir. Bireysel emeklilik şirketleri yapısal kırılmaları anlayarak ve öngörerek pazarlama politikaları başta olmak üzere tercihlerini belirleyebilir. Diğer taraftan, kamu otoritesi hangi yasal değişikliğin etkili olabileceğini saptayarak rasyonel adımlar atabilir ve/veya adımlarını çeşitlendirebilir. Bununla beraber şirket içi değişkenlerin de ele alınması önem taşımaktadır.

Önümüzdeki dönemde yapılacak çalışmalarda, bireysel emeklilik fon büyüklüğündeki yapısal değişmelerin mikro ölçekte şirket karlılığına, makro ölçekte ise tasarruflar kanalıyla iktisadi büyümeye katkıları incelenerek yapılacak reformların yönü tartışılabilir.

\section{Kaynakça}

Amerika Birleşik Devletleri Adalet Bakanlı̆̆ı ve Federal Ticaret Komisyonu (2010). Horizontal Merger Guidelines. [https:// www . justice . gov / atr / horizontal - merger - guidelines 08192010\#5c]. (Erişim: 14 Eylül 2020).

Aggarwal, R. ve Goodell, J. (2013). PoliticalEconomy of Pension Plans: Impact of Institutions. Gender, and Culture. Journal of Banking \& Finance. 37(6). 1860-1879.

Akgiray, V., Peksevim, S. ve Sener, E. (2016). Emeklilik Fonları ve Finansal İstikrar: Şili ve Türkiye Örneklerinden Dersler. Finans ve Bankacılık Çalışmaları Dergisi. 5(2). 1-20.

Antolín, P. ve Stewart F. (2009). Private Pensions and Policy Responses to the Financial and Economic Crisis. OECD Working Papers on Insurance and Private Pensions. No. 36. OECD Publishing. Paris.

Bai, J. (1997). Estimating Multiple Breaks One at a Time. Econometric Theory. 13. 315-352.
Bai, J. ve Perron, P. (1998). Estimating and Testing Linear Models With Multiple Structural Changes. Econometrica. 66(1). 4778.

Bai, J. ve Perron, P. (2003). Computation and Analysis of Multiple Structural Change Models. Journal of Applied Econometrics. 18(1). 1-22.

Derelioğlu, D. (2001). Türkiye'de Özel Emeklilik Fonu Uygulamalart. TUGIAD Ekonomi Ödülleri 2000. İstanbul: Rota Yayın Yapım.

Emeklilik Gözetim Merkezi (2016). Bireysel Emeklilik Sistemi Gelişim Raporu 2015. İstanbul: Emeklilik Gözetim Merkezi.

Emeklilik Gözetim Merkezi (2019). Bireysel Emeklilik İstatistikleri. [https:// www . egm . org .tr/]. (Erişim: 19 Temmuz 2019).

EViews 11 (2019). Help Topics. [http://www.eviews.com/help/helpintro.html\#p age/content/testing-Stability_Diagnostics.html]. (Erişim: 13 Eylül 2020). 
Gökbayrak, Ş. (2010). Refah Devletlerinin Dönüşümü ve Özel Emeklilik Programları. Ankara: Siyasal Kitapevi.

Ildırar, M. ve Kıral, E. (2018). Piyasa Yapısı ve Yoğunlaşma: Türk Otomotiv Sektörü Üzerine Bir Analiz. Bolu Abant İzet Baysal Üniversitesi Sosyal Bilimler Enstitüsü Dergisi. 18(1). 93117.

Hazine ve Maliye Bakanlı̆̆1 (2019a). Sigortacllik ve Bireysel Emeklilik Faaliyetleri Hakkında Rapor 2018. Sigorta Denetleme Kurulu.

Hazine ve Maliye Bakanlı̆̆ (2019b). Yeni Ekonomi Programı: Yapısal Dönüşüm Adımları.

Holzmann, R. (2012). Global Pension Systems and Their Reform Worldwide Drivers, Trends and Challenges. The World Bank Social Protection\&Labor, Discussion Paper. No.1213. 1-20.

Kalkınma Bakanlığ1 (2018a). On Birinci Kalkınma Planı Sosyal Güvenlik Sisteminin Sürdürülebilirliği Özel İhtisas Komisyonu Raporu. Ankara.

Kalkınma Bakanlı̆̆ı (2018b). $2018 \quad$ Yıll Programı. Ankara.

Kara, S. ve Ylldı, Y. (2016). Türkiye'de Bireysel Emeklilik Sistemi: 2012 Sonras1 Yapılan Reformlar ve Beklentiler. Issletme ve Iktisat Çalışmaları Dergisi. 4(1). 23-45.

Kwoka, J. E. (1977). Large Firm Dominance and Price-Cost Margins in Manufacturing Industries. Southern Economic Journal. 44(1). 183-189.

Miralles, M. P., Romero, C. ve Whitehouse, E. (2012). International Patterns of Pension Provision II, A Worldwide Overview of Facts and Figures. The World Bank Social Protection\&Labor, Discussion Paper. No.1211. 1-205.

Mutluer Kurul, D. (2011). Türk Bankacilık Sektörüne İlişkin Yoğunlaşma ve Hakimiyet Göstergeleri. Türkiye Cumhuriyet Merkez Bankası Ekonomi Notları. (2011-5).

OECD (2013). Pensions at a Glance 2013: OECD and G20 Indicators, OECD Publishing. France.

OECD (2014). Pensions Outlook 2014. OECD Pensions Outlook, OECD Publishing, Paris.
OECD (2017a). Pensions at a Glance 2017: OECD and G20 Indicators, OECD Publishing, Paris.

OECD (2017b). OECD Pension Markets in Focus 2017, OECD Publishing, Paris.

OECD (2018a). OECD Pensions Outlook 2018, OECD Pensions Outlook, OECD Publishing, Paris.

OECD (2018b). OECD Pension Markets in Focus 2018, OECD Publishing, Paris.

OECD (2018c). Market Concentration. Issues Paper By the Secretariat, DAF / COMP / WD (2018) 46 . [https:// one . oecd . org / document/DAF/COMP/WD(2018)46/en/pdf]. (Erişim: 10 Eylül 2020).

OECD (2019a). OECD Pension Markets in Focus 2019. OECD Publishing, Paris.

OECD (2019b). Pensions at a Glance 2019: OECD and G20 Indicators, OECD Publishing, Paris.

Peksevim, S. ve Akgiray V. (2019). Reforming the Pension System in Turkey: Comparison of Mandatory and Auto-Enrolment Pension Systems in Selected OECD Countries, OECD Publishing, Paris.

Pino, A. ve Yermo, J. (2010). The Impact of the 2007-2009 Crisis on Social Security and Private Pension Funds: A Threat to Their Financial Soundness? International Social Security Review. 63(2). 5-30.

T.C. Resmi Gazete (2001). 4632 Say1l Bireysel Emeklilik Tasarruf ve Yatırım Sistemi Kanunu. 24366. 7 Nisan 2001.

Türkiye Cumhuriyeti Cumhurbaşkanlığı Strateji ve Bütçe Başkanlığ Kalkınma Planı (2019-2023).

Türkiye İstatistik Kurumu (2016). Sanayi ve Hizmet Sektörlerinde Yoğunlaşma, 2014. [http://www.tuik.gov.tr/PreHaberBultenleri.do;j sessionid=VSQsYQGQ2jBhttTRxd2rLrkJbTD wpM0JvdNQppXVphBth0GQGJmQ!91551679 6?id=21721]. (Erişim: 13 Eylül 2020).

Türkiye Sermaye Piyasaları Birliği (2019). Portföy Yönetim Şirketlerinin Toplu Faaliyet Verileri (2013-2019). Eylül 2019. [https://www.tspb.org.tr/tr/veriler/]. (Erişim: 31 Aralık 2019). 